\title{
Cold-Season Tornadoes: Climatological and Meteorological Insights
}

\author{
SAMUEL J. CHILDS AND RUSS S. SCHUMACHER \\ Department of Atmospheric Science, Colorado State University, Fort Collins, Colorado \\ JOHN T. ALLEN \\ Department of Earth and Atmospheric Sciences, Central Michigan University, Mount Pleasant, Michigan
}

(Manuscript received 18 August 2017, in final form 1 March 2018)

\begin{abstract}
Tornadoes that occur during the cold season, defined here as November-February (NDJF), pose many societal risks, yet less attention has been given to their climatological trends and variability than their warmseason counterparts, and their meteorological environments have been studied relatively recently. This study aims to advance the current state of knowledge of cold-season tornadoes through analysis of these components. A climatology of all (E)F1-(E)F5 NDJF tornadoes from 1953 to 2015 across a domain of $25^{\circ}-42.5^{\circ} \mathrm{N}$, $75^{\circ}-100^{\circ} \mathrm{W}$ was developed. An increasing trend in cold-season tornado occurrence was found across much of the southeastern United States, with a bull's-eye in western Tennessee, while a decreasing trend was found across eastern Oklahoma. Spectral analysis reveals a cyclic pattern of enhanced NDJF counts every 3-7 years, coincident with the period of ENSO. La Niña episodes favor enhanced NDJF counts, but a stronger relationship was found with the Arctic Oscillation (AO). From a meteorological standpoint, the most-tornadic and least-tornadic NDJF seasons were compared using NCEP-NCAR reanalysis data of various severe weather and tornado parameters. The most-tornadic cold seasons are characterized by warm and moist conditions across the Southeast, with an anomalous mean trough across the western United States. In addition, analysis of the convective mode reveals that NDJF tornadoes are common in both discrete and linear storm modes, yet those associated with discrete supercells are more deadly. Taken together, the perspectives presented here provide a deeper understanding of NDJF tornadoes and their societal impacts, an understanding that serves to increase public awareness and reduce human casualty.
\end{abstract}

\section{Introduction}

Every year, approximately 1200 tornadoes occur across the United States and are responsible for, on average, around 60 fatalities (NSSL 2017). The majority of these tornadoes happen during the spring and summer months east of the Rocky Mountains. Yet clearly, tornado occurrence is not limited to the warm season, as the numerous major wintertime tornado events in the past few years affirm. For example, tornado outbreaks occurred during the week of Christmas in both 2012 and 2015, with the latter responsible for 25 fatalities across parts of Mississippi, Tennessee, and Texas. On 17 November 2013, more than 75 tornadoes tore through the Midwest, including the only November EF4 tornado in Illinois state history. The 30 tornadoes confirmed on this

Corresponding author: Samuel J. Childs, sjchilds@rams. colostate.edu day in Indiana make it the state's second-largest tornado day ever. The "Super Tuesday outbreak" of February 2008 also gained much publicity for its destruction: 27 significant $(\mathrm{EF} 2+)$ tornadoes were reported in this outbreak and were responsible for over 50 fatalities (NWS 2009; Livingston 2013). More recently, the winter of 2016/17 saw several major tornado events, including EF3 tornadoes in both Hattiesburg, Mississippi, and East New Orleans, Louisiana, in January 2017. In fact, the 134 tornado reports in January 2017 make it the second-most tornadic January in the modern record (NCEI 2017b). The destruction and casualties associated with such events are stark reminders that cold-season tornadoes can be just as impactful as their warm-season counterparts.

Publisher's Note: This article was revised on 14 June 2018 to include a revised version of Fig. 1 to replace an incorrect version that was originally published. 
Despite the wealth of tornado research in recent years, relatively little work has been pursued that specifically highlights the climatology and variability of cold-season tornadoes outside of the influence of $\mathrm{El}$ Niño-Southern Oscillation (ENSO). In perhaps the most comprehensive study to date, Galway and Pearson (1981) found that tornado outbreaks occurring between the months of December and February tend to happen in the Southeast and to be associated with a northward surge of moisture from the Gulf of Mexico and high wind shear. More recent studies have identified these events over both Australia and the United States and attempted to evaluate cold-season environments or those driven by predominantly high shear and lower CAPE through observational climatologies (Hanstrum et al. 2002; Guyer and Dean 2010; Sherburn et al. 2016) and modeling approaches (Cohen et al. 2015, 2017; King et al. 2017). In addition, links between cold-season tornado occurrence and ENSO have been made (Nunn and DeGaetano 2004; Cook and Schaefer 2008; Allen et al. 2015; Cook et al. 2017). These studies place specific emphasis on treating cold-season environments within the context of a broader research question, focus on a subset of tornadic events, and/or use a small temporal or spatial domain. Expanding the current state of knowledge of cold-season tornadoes is crucial, especially given their enhanced societal risks. For example, the public is more apt to overlook a tornado threat in wintertime, when they are generally not expecting one (Simmons and Sutter 2007). Cold-season tornadoes frequently occur at night (Davies and Fischer 2009; Sherburn et al. 2016), and Kis and Straka (2010) showed that over half of significant $(\mathrm{F} 2+)$ nocturnal tornadoes during a 3-yr period occurred during the cool season (16 October15 February). Cold-season tornado occurrence is also clustered around the socioeconomically vulnerable southeastern United States (Cutter et al. 2003; Ashley 2007), increasing the potential for casualties and destruction when they occur (Ashley et al. 2008; Emrich and Cutter 2011). Therefore, it is important that coldseason tornado risk and warning messages be communicated effectively to help save lives (Childs and Schumacher 2018). It is within this context that this study introduces a comprehensive climatological analysis of cold-season tornadoes and their variability, while also investigating the meteorological characteristics of such events.

The rest of the article proceeds as follows. Section 2 establishes the temporal and spatial characteristics of the tornadoes to be included in the climatology. Next, results are given from two core perspectives. Section 3 assesses the temporal and spatial trends in cold-season tornadoes and their relationship to teleconnection patterns, specifically ENSO and the Arctic Oscillation
(AO). Section 4 uses data from the NCEP-NCAR reanalysis dataset to investigate the meteorological environments that characterize cold-season tornado activity. A brief analysis of convective modes of cold-season tornadoes is also presented in this section. Finally, key points are summarized and discussed in section 5 .

\section{Tornado data}

In developing the cold-season climatology, a few preliminary decisions must be made regarding the temporal, spatial, and intensity ranges of the tornado data used. All tornadoes are analyzed by counts, as taken from the National Centers for Environmental Information (NCEI) Storm Data archive, which contains tornado reports from 1950 through the near-present day. The tornado day metric, which often is studied in place of counts, is not investigated here because of the small sample size of tornado days in the four cold-season months analyzed.

\section{a. Temporal domain}

The four months with the lowest average U.S. tornado counts, namely November-February (NDJF), are the focus of this study (NCEI 2017a). In establishing the starting year for analysis, it must be considered that tornado data are suspect prior to the founding of the National Severe Storms Forecast Center in 1953, after which reporting became more systematic (Schaefer and Edwards 1999; Verbout et al. 2006; Agee and Childs 2014). Therefore, many recent tornado climatology studies begin their analysis with 1953 or 1954 (Agee and Childs 2014; Brooks et al. 2014; Elsner et al. 2015; Agee et al. 2016). This study follows suit and commences the NDJF climatology with November 1953. The analysis ends with February 2015, for a total of 62 cold seasons.

\section{b. Intensity range}

Total U.S. tornado counts, considering the full (E)Fscale spectrum, show an upward trend over time (Verbout et al. 2006; Brooks et al. 2014; Elsner et al. 2015). However, this trend is misleading as result of a variety of factors such as technological advancements, National Weather Service (NWS) modernization (Edwards et al. 2013), population growth (Anderson et al. 2007), and a growing public interest in chasing and viewing tornadoes (McCarthy and Schaefer 2004; Edwards et al. 2013; Elsner et al. 2013). The advent of the Fujita (F) scale in 1974 revolutionized the field of tornado reporting, but issues remain in the tornado data. For example, Verbout et al. (2006) and Agee and Childs (2014) note an over- (under-) count of F2 (F1) tornadoes prior to 1974, and intensity statistics must correct for this accordingly. The enhanced Fujita (EF) scale was created in 2007 to help 


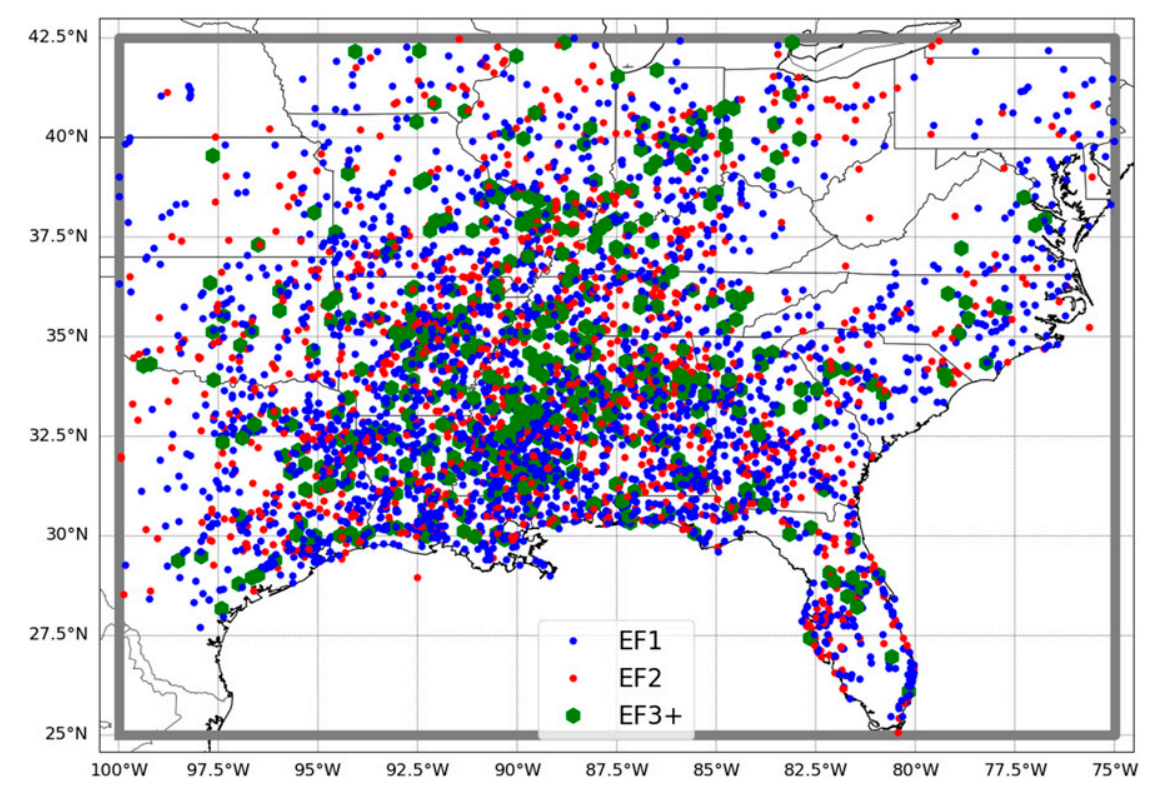

FIG. 1. NDJF (E)F1-(E)F5 tornadoes from 1953 to 2015. Each dot represents the starting location of a tornado, color denotes a tornado's EF-scale intensity, and the large gray box denotes the boundaries of the study domain.

refine the original $\mathrm{F}$ scale. This EF scale is still young, but early indications are that it may favor EF1-2 tornadoes at the expense of EF0 tornadoes and may result in a downward rating of higher-end tornadoes as a result of the reduced numbers of damage indicators (Edwards and Brooks 2010).

The main issue regarding the selection of tornado intensities for analysis rests with the (E)F0 record. Verbout et al. (2006) and Agee and Childs (2014) also explain how the introduction of Doppler radar in the mid-1990s vastly improved our capability to detect weak tornadoes using radar, thereby causing a huge spike in EF0 tornado reports at that time. This uptick distorts the overall record, so much so that many studies (including this one) elect to use only the (E)F1-(E)F5 tornado record (Brooks et al. 2014; Widen et al. 2015; Agee et al. 2016; Guo et al. 2016), which does not show an appreciable trend over time (Verbout et al. 2006). By using only (E)F1-(E)F5 tornadoes, this study also narrows its focus to those tornadoes that are most probable to cause damage and casualties. For an in-depth look at these and other issues with the tornado database over time, the reader is directed to Doswell and Burgess (1988), Verbout et al. (2006), and Agee and Childs (2014).

\section{c. Spatial domain}

While tornadoes can occur anywhere across the continental United States (CONUS), most of the activity is east of the Rocky Mountains. During the cold season, the region of interest is confined to the Southeast and the
Mississippi valley, as illustrated using environmental proxies (Tippett et al. 2014) and shown in Fig. 1, where each point represents the starting position of the tornado from Storm Data. Therefore, this study uses a domain of $25^{\circ}-42.5^{\circ} \mathrm{N}, 75^{\circ}-100^{\circ} \mathrm{W}$, as outlined in Fig. 1 . The tornado data were examined to combine duplicate entries (e.g., if the same tornado passes through two or more states, it receives separate entries in Storm Data), and in a few cases tornadoes were excluded because of a missing starting latitude-longitude position. This yielded a total of 4293 (E)F1-(E)F5 NDJF tornadoes over the 62 cold seasons within the domain, representing $96.4 \%$ of all reported NDJF tornadoes in the CONUS during this time. To summarize, this climatology includes all (E)F1-(E)F5 tornadoes in the months of NDJF from 1953 to 2015 within the spatial domain of $25^{\circ}-42.5^{\circ} \mathrm{N}, 75^{\circ}-100^{\circ} \mathrm{W}$.

\section{Climatological perspective}

\section{a. Temporal and spatial trends}

Linear regression was used on time series of both annual and NDJF counts over the period 1953-2015 and reveals conflicting trends (Fig. 2). The annual (E)F1-(E)F5 record has a slope of 0.123 , which amounts to approximately one more tornado every 10 years. In comparison, the NDJF record has a slope of 0.488 , amounting to an increase of approximately one tornado every two cold seasons. In other words, NDJF tornado frequency is increasing at a greater pace than the annual trend in frequency. A bootstrap approach that computes 


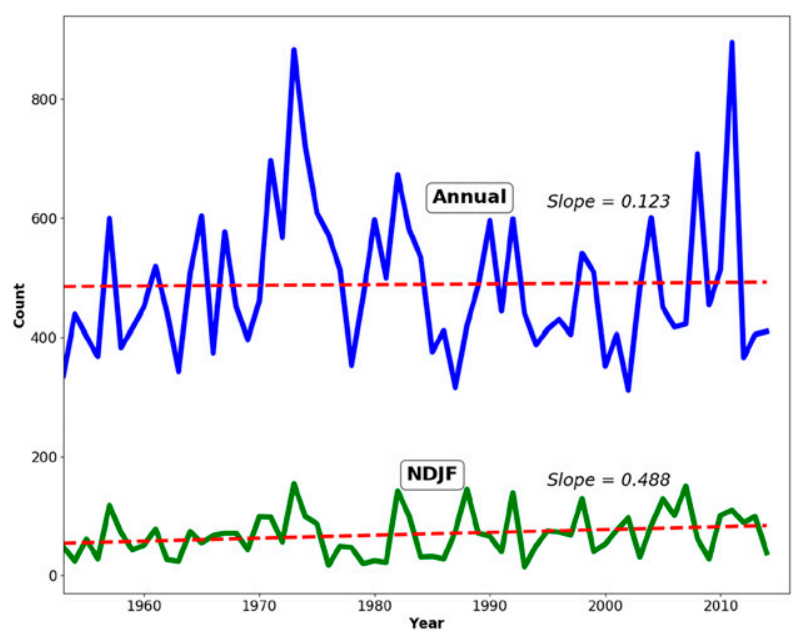

FIG. 2. Annual and NDJF (E)F1-(E)F5 tornado counts for the period 1953-2015 with linear trend lines.

trend lines from 500 randomly ordered NDJF time series shows that this trend is significantly different from zero at the $95 \%$ confidence level, whereas the annual trend is not. Some of the increase in NDJF counts can likely be attributed to nonmeteorological reporting factors, such as population bias, topography, and technological advancements, such as the WSR-88D network, which allow for formerly reported wind events to be classified as tornadoes. Yet these factors remain the same whether one is considering annual or NDJF tornadoes, so this rapid increase in the cold season likely reflects, at least in part, changes to the magnitudes of the meteorological parameters that characterize tornadic environments. Also apparent in Fig. 2 is the high variability in NDJF tornadoes (standard deviation = 36.75 ), which also exists and is increasing in the annual tornado record (Brooks et al. 2014; Tippett 2014). The 62 -yr record contains 10 cold seasons with greater than 100 tornadoes in the domain, the most active winter being 1973/74 with 154 reports. The lowest NDJF count was seen in 1993/94, when only 14 tornadoes occurred. With regard to tornado count trends for individual months, Table 1 suggests that the months of November and January (trends of +0.30 and +0.18 , respectively) contribute most to the overall NDJF increase, yet the trends in the individual months are not significant.

To assess this trend spatially, the study domain was divided into 70 grid boxes at $2.5^{\circ} \times 2.5^{\circ}$ resolution, consistent with the resolution of the NCEP-NCAR reanalysis dataset used later. Linear regression was performed for the NDJF tornado count time series within each grid box, and the resulting regression coefficients are shown in Fig. 3. The majority of the grid boxes show an increasing trend through time, with a bull's-eye of
TABLE 1. Monthly tornado counts and trends for the period $1953-2015$ within the study domain of $25^{\circ}-42.5^{\circ} \mathrm{N}, 75^{\circ}-100^{\circ} \mathrm{W}$. The boldface NDJF trend denotes statistical significance.

\begin{tabular}{lccccc}
\hline \hline & Nov & Dec & Jan & Feb & NDJF \\
\hline Total count & 1544 & 858 & 853 & 1038 & 4293 \\
Trend & 0.302 & -0.045 & 0.177 & 0.053 & $\mathbf{0 . 4 8 8}$
\end{tabular}

increasing counts across central and western Tennessee, stretching southward along the Mississippi River. Despite being known as the heart of "Tornado Alley," the largest decreasing trend is seen over eastern Oklahoma. Interestingly, these results are similar to the spatial shifts in annual tornado frequency reported by Agee et al. (2016) and the decrease in tornado days across Oklahoma found by Farney and Dixon (2015), suggesting that the cold season may be playing a larger role than expected in driving annual spatial changes.

Testing for the statistical significance of trends found that two grid boxes have a significant increasing trend, and one grid box has a significant decreasing trend at either the $95 \%$ or $99 \%$ confidence interval. A bootstrap test of 500 random time series affirms the significance for each grid box. Curiously, all three of these grid boxes are located between $35^{\circ}$ and $37.5^{\circ} \mathrm{N}$, with the significantly increasing grid boxes in central Tennessee $\left(85^{\circ}-87.5^{\circ} \mathrm{W}\right)$ and western Tennessee $\left(87.5^{\circ}-90^{\circ} \mathrm{W}\right)$, and the significantly decreasing grid box in eastern Oklahoma $\left(95^{\circ}-97.5^{\circ} \mathrm{W}\right)$. Time series of these three grid boxes (not shown) reveal a gradual decrease in NDJF counts for the Oklahoma grid box, but a sharper uptick in counts starting in the mid-1990s for the Tennessee grid boxes. This could be due in part to the advent of Doppler radar, but again, the (E)F0 record, which is not considered here, is by far the most affected by Doppler radar. The sensitivity of grid-box size on trends has also been tested by using $2^{\circ} \times 2^{\circ}$ and $3^{\circ} \times 3^{\circ}$ resolutions. The results are qualitatively similar, with significant increasing trends (at the 99\% confidence level) in central Tennessee and significant decreasing trends in eastern Oklahoma (at the $95 \%$ and $99 \%$ confidence levels) for both $2^{\circ} \times 2^{\circ}$ and $3^{\circ} \times 3^{\circ}$ grid-box sizes.

\section{b. Tornado intensity}

It is also of interest to assess the strength of coldseason tornadoes. As such, Table 2 lists the total numbers of tornadoes in each (E)F1-(E)F5 rating category for each month and NDJF over the period 1953-2015. Over half of all NDJF tornadoes fall into the (E)F1 category, and only $11 \%$ of NDJF tornadoes have been rated $(\mathrm{E}) \mathrm{F} 3$ or greater. The $(\mathrm{E}) \mathrm{F} 1-(\mathrm{E}) \mathrm{F} 2$ ratings also dominate each individual month's tornado count. This 


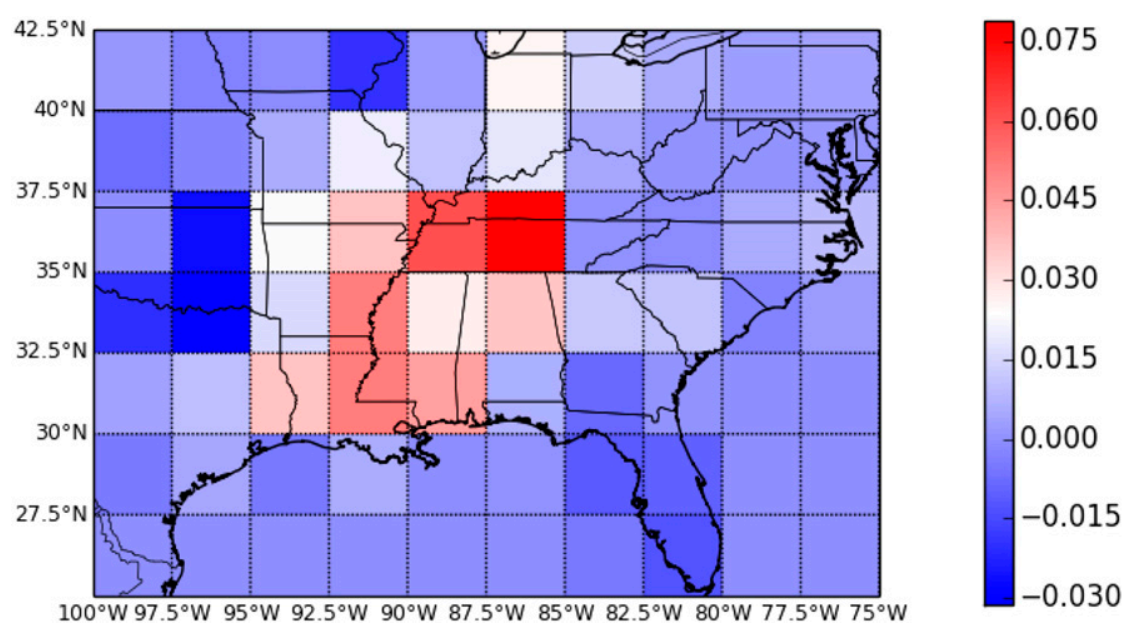

FIG. 3. NDJF tornado count regression coefficient (i.e., trend) for the period 1953-2015 for each $2.5^{\circ} \times 2.5^{\circ}$ grid box within the study domain.

weighting toward weaker tornadoes also exists in the annual distribution, in which $89 \%$ of tornadoes are rated (E)F0 or (E)F1 (Strader et al. 2015). As discussed later, weaker tornadoes are common in a low-CAPE-highshear regime that tends to prevail in winter environments across the Southeast (Schneider et al. 2006; Guyer and Dean 2010; Sherburn and Parker 2014; Sherburn et al. 2016). Although December sees relatively few tornadoes overall, Table 2 reveals a greater proportion of stronger tornadoes during December than in any other month. Specifically, (E)F3-(E)F5 tornadoes account for $12.6 \%$ of the total December tornado count through the data record, compared to $10.8 \%$ in November, 9.8\% in February, and 9.1\% in January. Further, of the three (E)F5 tornadoes in the NDJF record, two of those occurred in December (albeit in 1953 and 1957, when reporting practices are more suspect).

\section{c. Spectral analysis and teleconnection influences}

Several recent studies have attempted to link teleconnection patterns with oscillating phases to tornado frequency (Thompson and Roundy 2013; Allen et al. 2015; Sparrow and Mercer 2016; Cook et al. 2017), yet these studies have not focused specifically on NDJF tornadoes, instead considering the meteorological seasons. Before looking for teleconnection relationships, it is of worth to assess whether any periodicity exists in the cold-season tornado climatology. To do so, a normalized power spectrum for each individual month and NDJF tornado count time series was calculated, as displayed in Fig. 4. Using the approach of Welch (1967), each time series was chunked in half, and a Hanning window with $50 \%$ overlap was employed, yielding four degrees of freedom for each time series. Figure 4 reveals that all months and seasons show at least one discernible spectral peak, and every month except January has a peak in the $0.13-0.26$ cycles per season range. Physically, this corresponds to a month or season of enhanced tornado counts every 3-7 years, a noteworthy finding since this aligns with the period of ENSO (Allan 1999). Each notable peak is checked for statistical significance using the $F$ test, which compares a rednoise time series drawn from a random normal distribution to the standardized tornado time series. It is found that the November, February, DJF, and NDJF power spectra each contain at least one significant spectral peak on a 3-6-yr cycle.

To investigate the potential effects of ENSO on coldseason tornado counts, average oceanic Niño indexes (ONIs) for the four 3-month periods of OctoberDecember (OND), November-January (NDJ), DJF, and January-March (JFM) were computed for each season during the 62-yr period from Climate Prediction Center (CPC) archives (http://origin.cpc.ncep.noaa.gov/ products/analysis_monitoring/ensostuff/ONI_v4.shtml). For this study, an average ONI $\geq 0.5$ is defined as El Niño (EN), ONI $\leq-0.5$ is defined as La Niña (LN),

TABLE 2. Monthly tornado counts for each (E)F1-(E)F5 rating, with the percent contribution to the NDJF total in parentheses (1953-2015).

\begin{tabular}{lrrrrc}
\hline \hline Intensity & Nov & Dec & Jan & Feb & NDJF \\
\hline (E)F1 & 900 & 463 & 508 & 628 & $2499(58 \%)$ \\
(E)F2 & 476 & 287 & 267 & 308 & $1338(31 \%)$ \\
(E)F3 & 146 & 94 & 67 & 84 & $391(9 \%)$ \\
(E)F4 & 22 & 12 & 11 & 17 & $62(1 \%)$ \\
(E)F5 & 0 & 2 & 0 & 1 & $3(<1 \%)$ \\
\hline
\end{tabular}



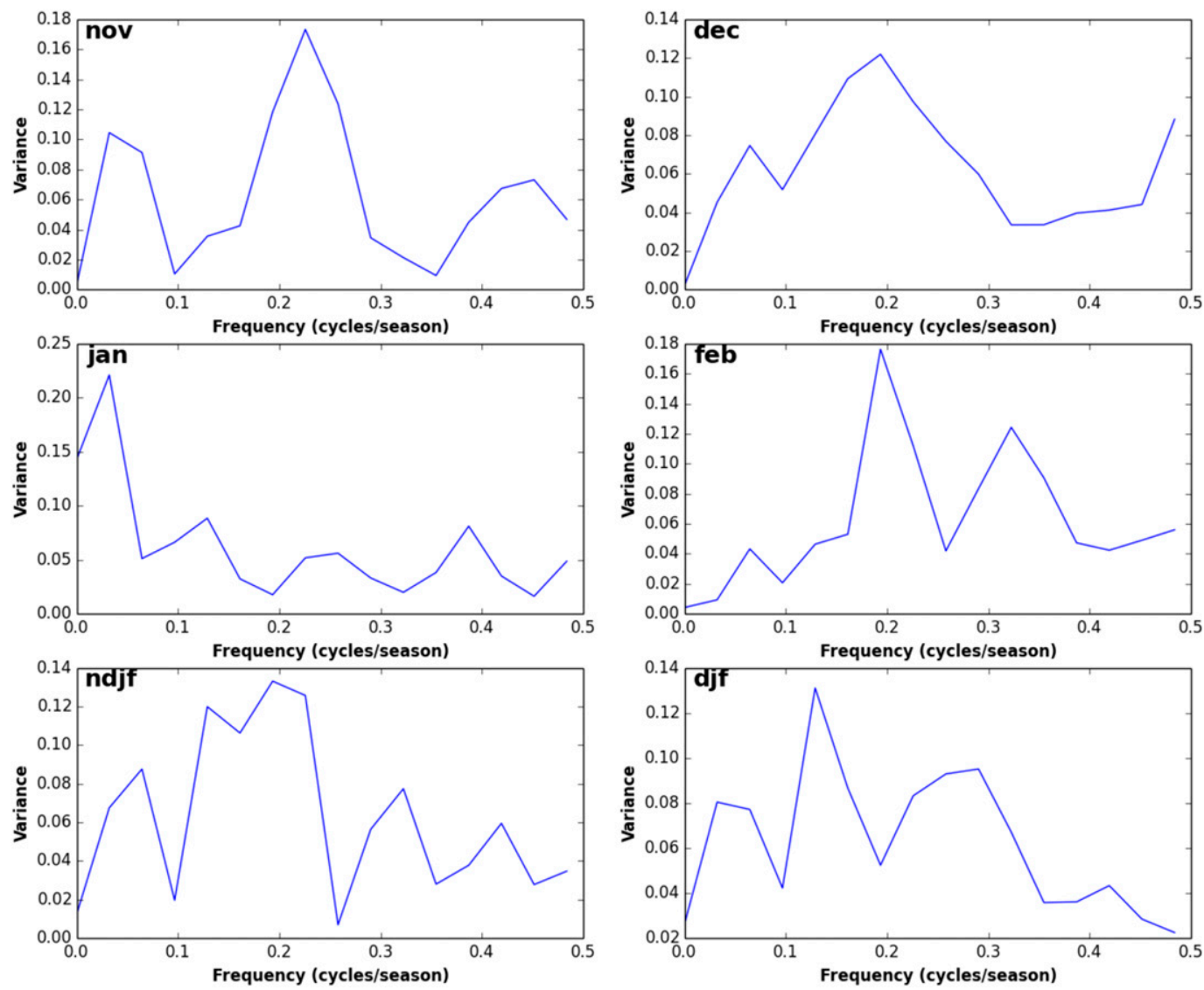

FIG. 4. Normalized power spectra for tornado counts of individual months and seasons. Variance is shown as a function of frequency (cycles per cold season).

and $-0.5<$ ONI $<0.5$ is defined as neutral $(\mathrm{N}) .{ }^{1}$ Fortuitously, this definition yielded $21 \mathrm{EN}, 21 \mathrm{LN}$, and $20 \mathrm{~N}$ seasons for the data period, allowing for easy statistical comparison. It is noted that the definition employed here is not directly transferrable to operational use, being slightly different from the official CPC definition, yet the results yield a matching ENSO phase declaration when compared with that in the official CPC archives for each season. In addition to ENSO, the AO was also analyzed because of its association with the polar vortex, which can influence U.S. wintertime conditions

\footnotetext{
${ }^{1}$ This definition differs slightly from the official CPC definition of ENSO events, which defines EN as five consecutive 3-month $\mathrm{ONI}>0.5$ and $\mathrm{LN}$ as five consecutive 3 -month $\mathrm{ONI}<-0.5$. Since using five consecutive 3-month averages here would induce additional overlap into months beyond NDJF (e.g., SON average includes September and October), the average ONI for OND, NDJ, $\mathrm{DJF}$, and JFM is adopted to here to declare a season as EN, LN, or $\mathrm{N}$. Upon cross checking with the official CPC definition, it is found that the definition adopted here is consistent with the official ENSO phase declaration for all years.
}

(Thompson and Wallace 1998). The monthly AO index was obtained from the CPC archives (CPC 2012) and averaged over NDJF for each year. A 4-month average $\mathrm{AO}>0$ is defined as the positive phase, and $\mathrm{AO}<0$ is defined as the negative phase. Table 3 gives the average NDJF and monthly tornado counts under each ENSO and AO phase for the 1953-2015 period, and the associated Fig. 5 displays this result graphically via a scatterplot of ONI (Fig. 5a) and AO index (Fig. 5b) versus the normalized tornado count for each season. The NDJF season averages roughly 30 more tornadoes

TABLE 3. Average number of NDJF and monthly tornadoes for the period 1953-2015, given a particular ENSO or AO phase.

\begin{tabular}{lcccccc}
\hline \multicolumn{1}{c}{ Phase } & No. of seasons & NDJF & Nov & Dec & Jan & Feb \\
\hline El Niño & 21 & 62.0 & 24.4 & 15.5 & 10.5 & 11.7 \\
La Niña & 21 & 90.1 & 27.0 & 17.9 & 19.9 & 25.4 \\
Neutral & 20 & 54.9 & 23.3 & 7.8 & 10.8 & 13.0 \\
Positive AO & 24 & 85.8 & 29.7 & 16.9 & 18.9 & 20.3 \\
Negative AO & 38 & 58.8 & 21.9 & 11.9 & 10.5 & 14.5 \\
\hline
\end{tabular}



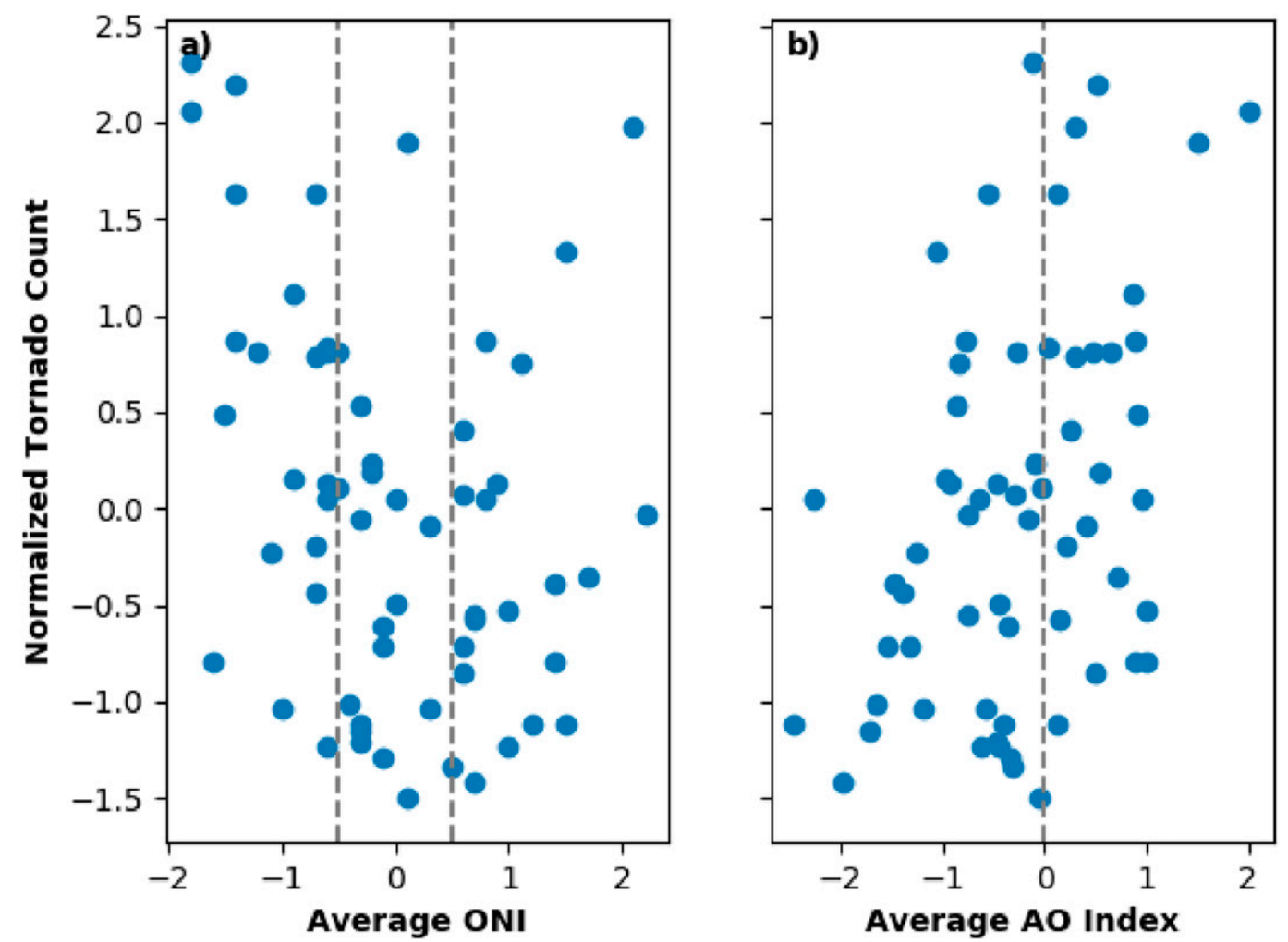

FIG. 5. Average NDJF (a) ONI and (b) AO index vs normalized NDJF tornado count for each cold season (1953-2015). The vertical dashed lines indicate the divisions between respective ENSO (LN, N, EN) and AO $(+,-)$ phases.

under $\mathrm{LN}$ compared to $\mathrm{EN}$ and $\mathrm{N}$ and also about 30 more tornadoes under positive AO than negative AO (a difference-of-means $t$ test reveals that the $\mathrm{LN} / \mathrm{N}$, $\mathrm{LN} / \mathrm{EN}$, and $\mathrm{AO}+/ \mathrm{AO}-\mathrm{NDJF}$ count differences are all significant at the $95 \%$ confidence level); moreover, each individual month also has its greatest average tornado count under these phases. The propensity for cold-season tornadoes to be favored during $\mathrm{LN}$ is consistent with previous work (Cook and Schaefer 2008; Allen et al. 2015). Furthermore, it is not surprising that a positivephase AO results in more tornadoes, since this phase is characterized by high pressure over the Arctic, a stronger jet stream that confines colder air farther north, and a northward-shifted storm track, allowing for warmer winters across the southern United States. It is also worth noting that the average tornado intensity (not shown) under each ENSO phase and the two AO phases is not significantly different; in other words, although tornadoes are more common under $\mathrm{LN}$ and positive AO conditions, they are not necessarily more intense.

Correlations were calculated between the tornado count and both the ENSO and AO time series, with the variance explained $r^{2}$ shown in Table 4. Correlation coefficients $r$ (not shown) with ENSO are negative, implying that as ONI decreases (i.e., toward LN), the tornado count increases. Correlation coefficients for $\mathrm{AO}$ are positive, implying more tornadoes under the positive phase. Only $10 \%$ of the variance in NDJF counts is explained by the ENSO phase, and $17 \%$ of the variance is explained by the AO phase. While these correlations are not high by most standards, a Pearson correlation test does reveal that they are statistically significant, as are the correlations between November tornado counts and $\mathrm{AO}$, as well as February tornado counts and ENSO (denoted by the italicized $r^{2}$ values in Table 4). Therefore, one can conclude that there is indeed some relationship between these teleconnection indices and cold-season tornado counts, a relationship that is likely one of modulating the environment in such a way as to support NDJF tornadoes, rather than explicitly causing

TABLE 4. Correlations $r^{2}$ between NDJF and monthly tornado counts and ENSO or AO index time series. Italicized $r^{2}$ values indicate statistically significant correlations via the Pearson correlation test.

\begin{tabular}{cccccc}
\hline \hline Teleconnection & NDJF & Nov & Dec & Jan & Feb \\
\hline ENSO & 0.090 & 0.011 & 0.003 & 0.059 & 0.095 \\
AO & 0.168 & 0.104 & 0.001 & 0.041 & 0.030 \\
\hline
\end{tabular}


them (Nunn and DeGaetano 2004). The findings presented here add a fresh perspective to previous work, particularly by exploring the long-term variability of tornado frequency and intensity as opposed to outbreaks (Cook et al. 2017) and by demonstrating the connection between the AO and cold-season tornadoes, which has potential implications for forecasting NDJF tornadoes. For example, recent work (Lepore et al. 2017) has shown the capacity to predict ENSO months in advance and thereby provide spatial probabilistic seasonal forecasts for spring severe storms; thus, the ENSO-AO associations shown here potentially could be applied in a predictive capacity for public outlooks for an upcoming winter season.

\section{Meteorological perspective}

Having established a comprehensive climatology of cold-season tornadoes from 1953 to 2015, the next step is to investigate the meteorological factors associated with their occurrence. Several parameters have been studied and proven useful for forecasting tornadoes, specifically measurements of convective available potential energy (CAPE), vertical wind shear, storm-relative helicity (SRH), lifting condensation level (LCL) heights, and composite indices such as the significant tornado parameter (STP) and energy-helicity index (EHI; e.g., Johns et al. 1993; Rasmussen and Blanchard 1998; Thompson et al. 2003, 2007, 2012; Guyer et al. 2006). However, many of these parameters struggle to capture cold-season tornado environments because of the limited CAPE present during the cold season (Davies 2006; Guyer and Dean 2010; Tippett et al. 2014; Sherburn et al. 2016). Furthermore, Grams et al. (2012) assessed convective mode frequencies of tornadoes but admitted that Southeast wintertime tornadoes prove the most difficult to forecast. An assessment of the convective mode that supports this assertion also is presented in this section.

Some insights into cold-season environments have been gleaned; for example Galway and Pearson (1981) found that winter tornado outbreaks tend to occur in the presence of rich low-level moisture due to transport via the low-level jet (LLJ) northeastward from the Gulf of Mexico. Guyer et al. (2006) showed that significant winter tornadoes tend to occur downstream of an upperlevel trough with a strong southerly or southwesterly LLJ $>30 \mathrm{kt}\left(1 \mathrm{kt}=0.51 \mathrm{~m} \mathrm{~s}^{-1}\right)$, which is similar to tornado environments during other seasons. Perhaps most characteristic of cold-season tornado environments is a low-CAPE-high-shear signal (Davies 2006; Guyer et al. 2006; Schneider et al. 2006; Sherburn and Parker 2014; Sherburn et al. 2016). In fact, Brooks (2009) found that the same value of CAPE $\times 0-1-\mathrm{km}$ bulk shear was more likely to be associated with severe weather in the southeastern United States during winter than during any other time of the year, likely because of the strength and frequency of the synoptic systems and associated boundaries that initiate winter convection. Simulations by King et al. (2017) showed rapid increases in surfacebased CAPE ahead of cool-season tornadoes, which can be attributed in part to increased surface moistening. Aiding this low-CAPE-high-shear paradigm is the propensity for cold-season tornadoes to happen during the overnight hours, particularly across the Southeast (Davies and Fischer 2009; Kis and Straka 2010; Sherburn et al. 2016). Sherburn and Parker (2014) found that a combination of a $0-3-\mathrm{km}$ lapse rate and a 700-500-hPa lapse rate works best at discriminating between significant severe low-CAPE-high-shear environments and null events, with effective shear (Thompson et al. 2007) also adding skill specifically for low-CAPEhigh-shear tornado environments. The low-CAPE-highshear environment also has been found for cool-season tornadoes in Australia (Hanstrum et al. 2002; Kounkou et al. 2009). Modeling environments of cold-season tornadoes is challenging because of the need for planetary boundary layer (PBL) schemes to accurately represent low-level thermodynamic and wind profiles (Cohen et al. 2015). As such, Cohen et al. (2017) tested several local, nonlocal, and hybrid PBL schemes against a sounding dataset and found that the hybrid nonlocal-local PBL scheme most closely matches the observations of several severe weather parameters and PBL depth. They attributed this result to the ability of the hybrid scheme to account for both enhanced PBL mixing due to enhanced vertical shear and suppressed PBL mixing due to low instability in cold-season environments. Finally, this study does not attempt to discern past or project future trends in tornado parameters, a difficult task that is the topic of several other studies (Gensini and Ashley 2011; Diffenbaugh et al. 2013; Robinson et al. 2013; Lu et al. 2015).

\section{a. Synoptic and mesoscale environments}

To study the environmental conditions of cold-season tornadoes, both monthly and 6-hourly means of several parameters were taken from the NCEP-NCAR reanalysis (Kalnay et al. 1996), with sea surface temperatures (SSTs) taken from the Centennial in situ Observation-Based Estimates (COBE-SST2) dataset (Hirahara et al. 2014). Although its coarse spatial and temporal resolutions limit the robustness of the analysis for small-scale variations in kinematic or instability parameters, the NCEP-NCAR reanalysis was favored here for its longer time period compared to other modern reanalyses, assisting with characterizing the large 
interannual variability. Monthly variables selected include precipitable water (PWAT) and relative humidity (RH), since sufficient moisture is necessary for convective development, and low-level moisture is an important component in cold-season tornado events (e.g., Galway and Pearson 1981). Since the surface-based lifted index (SLI; Hales and Doswell 1982) is a broader and less detailed method of measuring instability compared to CAPE, and has been found useful in discerning tornado environments (Johns et al. 1993; Sherburn et al. 2016), it was used to assess instability on the monthly scale. Indeed, the more sensitive CAPE-derived parameters tend to struggle when representing tornado environments on an average basis in winter (Sherburn and Parker 2014). Monthly mean surface temperature and surface pressure also were analyzed; though temperature and pressure do not cause tornadoes, they can serve to modify other atmospheric parameters such that the environment becomes more or less favorable for tornadoes. Monthly SSTs, particularly those of the Gulf of Mexico (GOM), were investigated because of the role of the GOM as a heat and moisture source for the southern and central United States via the LLJ (Weaver et al. 2012) and its associated influence on U.S. regional tornado activity (Molina et al. 2016).

With finer-scale data available in the 6-hourly analyses, values of common tornado predictors, namely, the surface-based and mixed-layer CAPE (SBCAPE and MLCAPE, respectively), low-level $(0-1 \mathrm{~km})$ and deeplayer $(0-6 \mathrm{~km})$ bulk wind difference (BWD), 0-1- and 0-3-km SRH, and fixed-layer STP, were calculated from a reanalysis archive of derived convective parameters developed by the third author. Also included in the 6-hourly dataset were mixed-layer (i.e., lowest $50 \mathrm{hPa}$ ) specific humidity, for comparison with the monthly moisture variables, and three lapse rate measurements (0-3 and $2-4 \mathrm{~km}$ and $700-500 \mathrm{hPa}$ ) that have been included as part of several multiparameter tornado indices (Craven 2000; Brooks et al. 2003; Sherburn and Parker 2014; Sherburn et al. 2016). One limitation of 6-hourly time steps is that relatively large differences from potential tornado environments can skew means; in addition, using the coarse $2.5^{\circ} \times 2.5^{\circ}$ grid may cause parameters such as SRH and STP, which are sensitive to large changes in the proximity of small-scale features, to be underestimated. All meteorological variables were averaged across NDJF over the same spatial domain as the climatological analysis in section 3 $\left(25^{\circ}-42.5^{\circ} \mathrm{N}, 75-100^{\circ} \mathrm{W}\right)$. In attempting to answer the question what makes a particular NDJF season more tornadic than another, variables were composited and compared for the 10 most-tornadic and 10 least-tornadic NDJF seasons over the 62-yr period (Table 5).
TABLE 5. Lists of the 10 most-tornadic and 10 least-tornadic cold seasons, with respective NDJF tornado counts, during the period 1953-2015.

\begin{tabular}{ccccc}
\hline \multicolumn{2}{c}{ Most tornadic } & & \multicolumn{2}{c}{ Least tornadic } \\
\cline { 5 - 5 } Year & Count & & Year & Count \\
\hline $1973 / 74$ & 154 & & $1993 / 94$ & 14 \\
$2007 / 08$ & 150 & & $1976 / 77$ & 17 \\
$1988 / 89$ & 145 & & $1979 / 80$ & 20 \\
$1982 / 83$ & 142 & & $1981 / 82$ & 22 \\
$1992 / 93$ & 139 & & $1963 / 64$ & 24 \\
$1998 / 99$ & 129 & & $1954 / 55$ & 24 \\
$2005 / 06$ & 129 & & $1980 / 81$ & 25 \\
$1957 / 58$ & 118 & & $1962 / 63$ & 27 \\
$2011 / 12$ & 110 & $2009 / 10$ & 28 \\
$2006 / 07$ & 101 & $1986 / 87$ & 28 \\
\hline
\end{tabular}

\section{1) Monthly SYNOPTIC AND SURFACE VARIABLES}

Synoptically, years with enhanced cold-season tornado activity are characterized by an anomalously deep trough over the western United States and an associated ridge over the eastern United States (Fig. 6). Such a pattern also results in lower 500-hPa heights in the North Atlantic, indicative of the positive-phase AO pattern shown earlier to favor enhanced NDJF tornado counts.

For surface variables, 4-month NDJF means for the 10 most-tornadic and 10 least-tornadic cold seasons are computed, with the least-tornadic seasonal mean subtracted from the most-tornadic seasonal mean to make the difference plots in Fig. 7. It is immediately clear that the domain is warmer and more moist during enhanced NDJF seasons, with mean NDJF surface temperatures up to $2^{\circ} \mathrm{C}$ higher and $\mathrm{RH}$ values $2 \%-8 \%$ higher in seasons of greatest tornado counts (Figs. 7a,b). Mosttornadic seasons also exhibit higher instability (i.e., lower LI; note the inverted color bar in Fig. 7d) and lower surface pressure (Fig. 7e). Similar spatial patterns are noted in the PWAT (Fig. 7c), RH, and LI fields, in that the greatest enhancement in these variables during active seasons follows a southwest-to-northeast swath, suggesting an influence from the GOM. The lower surface pressure over the plains and the South in most-tornadic seasons also could signal more frequent extratropical cyclone passages, a scenario that favors convective development. In addition, higher pressure over the East Coast and North Atlantic Ocean aligns with positive-phase AO and La Niña patterns, which, as discussed in section 3, tend to favor more NDJF tornado activity.

Figure 8 shows SST differences between the most- and least-tornadic NDJF seasons, revealing comparatively warmer waters in the western GOM and cooler waters in the eastern GOM and along the East Coast during 


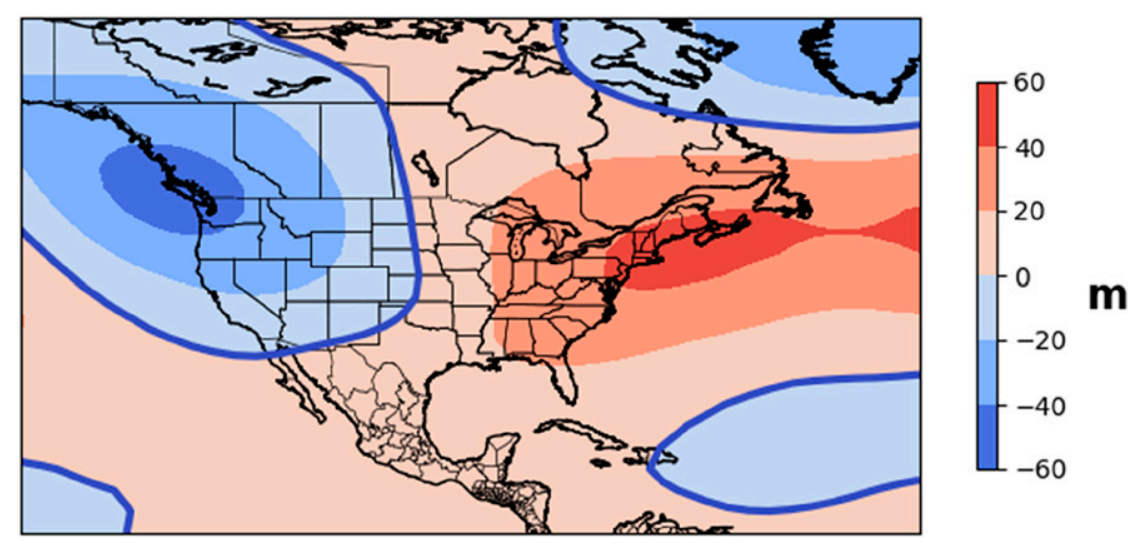

FIG. 6. Difference in mean NDJF 500-hPa heights for the most-tornadic - least-tornadic cold seasons.

most-tornadic seasons. The individual months of December, January, and February (not shown) had consistently warmer SSTs along the entire Gulf Coast during most-tornadic seasons, but November featured substantially cooler waters from New Orleans eastward in most-tornadic seasons, driving the overall NDJF cooling shown there. A warmer western GOM (with a presumably more moist overlying air mass) would provide a source for advection of above-normal moisture northward into Texas and Louisiana, which would then be driven eastward by the LLJ and an amplified wintertime storm track, providing the rich moisture necessary for convection and possible tornadoes (given other ingredients). Indeed, Molina et al. (2016) also found enhanced tornado activity in the southern U.S. spring with warmer GOM waters, suggesting this contribution is physically sensible.

\section{2) 6-HOURLY PARAMETERS}

To bolster the meteorological analysis, several severe weather parameters were investigated at 6-hourly intervals. As in the preceding synoptic analysis, parameters were examined by subtracting mean values of the 10 least-tornadic cold seasons from those of the 10 mosttornadic cold seasons. As discussed earlier, measures of CAPE, low-level and deep-layer BWD, SRH, STP, lapse rates, and mixed-layer specific humidity were analyzed. It is important to note that while combinations of these parameters are often good predictors of tornado events when considering the environment for individual convective storms, the aggregate values presented here are better served as a glimpse into the general environments in which cold-season tornadoes are prone to occur.

As mentioned, many previous studies affirm a lowCAPE-high-shear environment in cold-season severe weather (Davies 2006; Guyer et al. 2006; Schneider et al. 2006; Brooks 2009; Sherburn and Parker 2014; Sherburn et al. 2016; King et al. 2017), though the abilities of PBL schemes to accurately capture this environment are limited (Cohen et al. 2015, 2017). For the climatology established here, differences in 6-hourly NDJF mean parameters for the most-tornadic versus least-tornadic seasons are shown in Figs. 9 and 10. The gridbox size for these 6-hourly observations is of slightly finer resolution than that of the monthly parameter analysis, at $1.935^{\circ} \times$ $1.875^{\circ}$. While the magnitudes of both SBCAPE and MLCAPE are quite low, as expected given the lower instability during winter, both are comparatively higher in the most-tornadic seasons relative to the leasttornadic seasons, especially over and inland from the western GOM (Figs. 9a,b). For instance, up to $50 \mathrm{~J} \mathrm{~kg}^{-1}$ higher mean SBCAPE is noted across much of the lower Mississippi valley in most-tornadic NDJF seasons compared to least-tornadic seasons. This is consistent with a transport of moist, unstable air from over the comparatively warmer western GOM waters during the mosttornadic seasons shown above. Regarding bulk wind differences, while most-tornadic seasons have enhanced 0-1-km BWD domain wide compared to least-tornadic seasons (Fig. 9c), 0-6-km BWD is somewhat weaker across the Southeast, where NDJF tornadoes most frequently occur (Fig. 9d). This pattern is indicative of the mean wintertime upper-level jet pattern, with a trough in the plains and a ridge in the East, as suggested by the pattern of strongest 0-6-km BWD in Fig. 9d that dips southward over the central plains (trough) and extends northeastward into the middle Mississippi valley and Great Lakes area (ridge), and by 300-hPa wind speed differences between the most-tornadic and least-tornadic seasons (not shown). Under these conditions, the Mississippi valley lies in the exit region of the jet streak and 

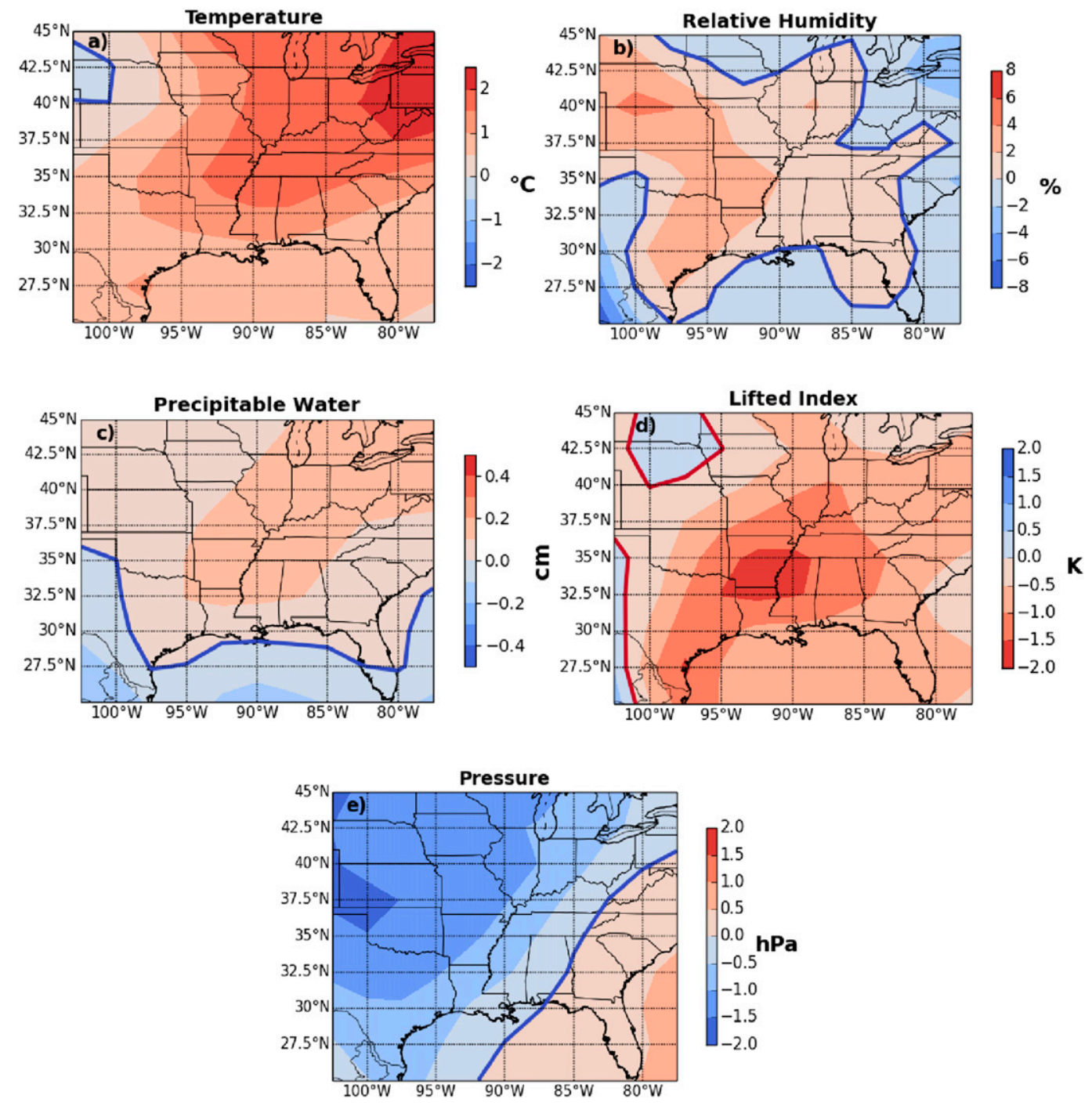

FIG. 7. Differences in mean NDJF surface values of (a) temperature, (b) RH, (c) PWAT, (d) LI, and (e) pressure from the NCEP-NCAR reanalysis for the most-tornadic - least-tornadic cold seasons.

downstream of the trough axis, which is a favored location for convection (Rose et al. 2004; Clark et al. 2009). Regardless of yearly variations in vertical BWD during the cold season, sharper horizontal and vertical temperature gradients with wintertime systems generate stronger wind fields than at other times of the year, so the resulting BWD is essentially always strong with these cold-season systems. For that reason, year-to-year variations in vertical BWD during the cold season are less important than the availability of low-level moisture downstream of upper troughs located over the central plains. These results affirm that vertical BWD is not the best discriminator between high and low NDJF tornado counts, at least in the seasonal mean sense. However, when sufficient CAPE is present in these cold-season environments of enhanced shear, albeit of lower magnitude than in warm-season environments, tornadoes become more likely.

In Fig. 10a, 0-1-km SRH is also lower across nearly the entire domain during the most-tornadic NDJF seasons. As with vertical BWD, given the frequency of strong synoptic systems in wintertime, SRH is already amplified compared to other times of year and thus is not expected to be on its own a discriminating factor (Cheng et al. 2016). This is in contrast to the warm season, when SRH becomes more relevant and useful (Thompson et al. 2007; Tippett et al. 2014). STP also lacks a discriminating ability in the mean sense (Fig. 10b), as it is already much reduced in the winter season because of its dependence on CAPE, which is also weaker during this period (Guyer and Dean 2010). 


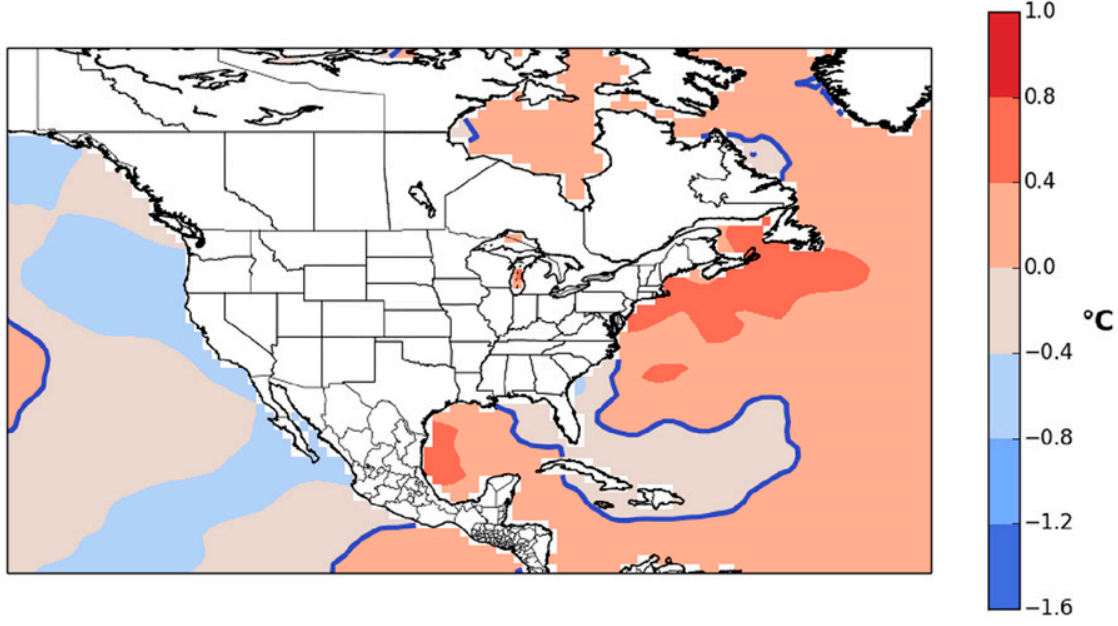

FIG. 8. Difference in mean NDJF SST for the most-tornadic - least-tornadic cold seasons.

The 700-500-hPa lapse rate is steeper across most of the domain during the most-tornadic seasons, by as much as $0.3^{\circ} \mathrm{C} \mathrm{km}^{-1}$ in the Mississippi valley region (Fig. 10c). The steeper lapse rates, combined with the enhanced low-level moisture in the most-tornadic seasons, indicates a more unstable environment (i.e., more CAPE) and thus a higher likelihood for severe weather. Finally, mixed layer specific humidity is greatly enhanced during most-tornadic seasons (Fig. 10d). In fact, the spatial pattern of specific humidity looks similar to the monthly moisture and LI variables shown before (Figs. 7b-d) and, thus, further confirms the importance of moisture transport from the warmer western GOM in creating favorable cold-season tornado environments. Additional analysis with the SPC Storm Mode database below also affirms that moisture may in fact be the predominant factor in NDJF tornado environments.

Perhaps a more discernible way to compare meteorological parameters between the most-tornadic and least-tornadic NDJF seasons is to tally the frequency at
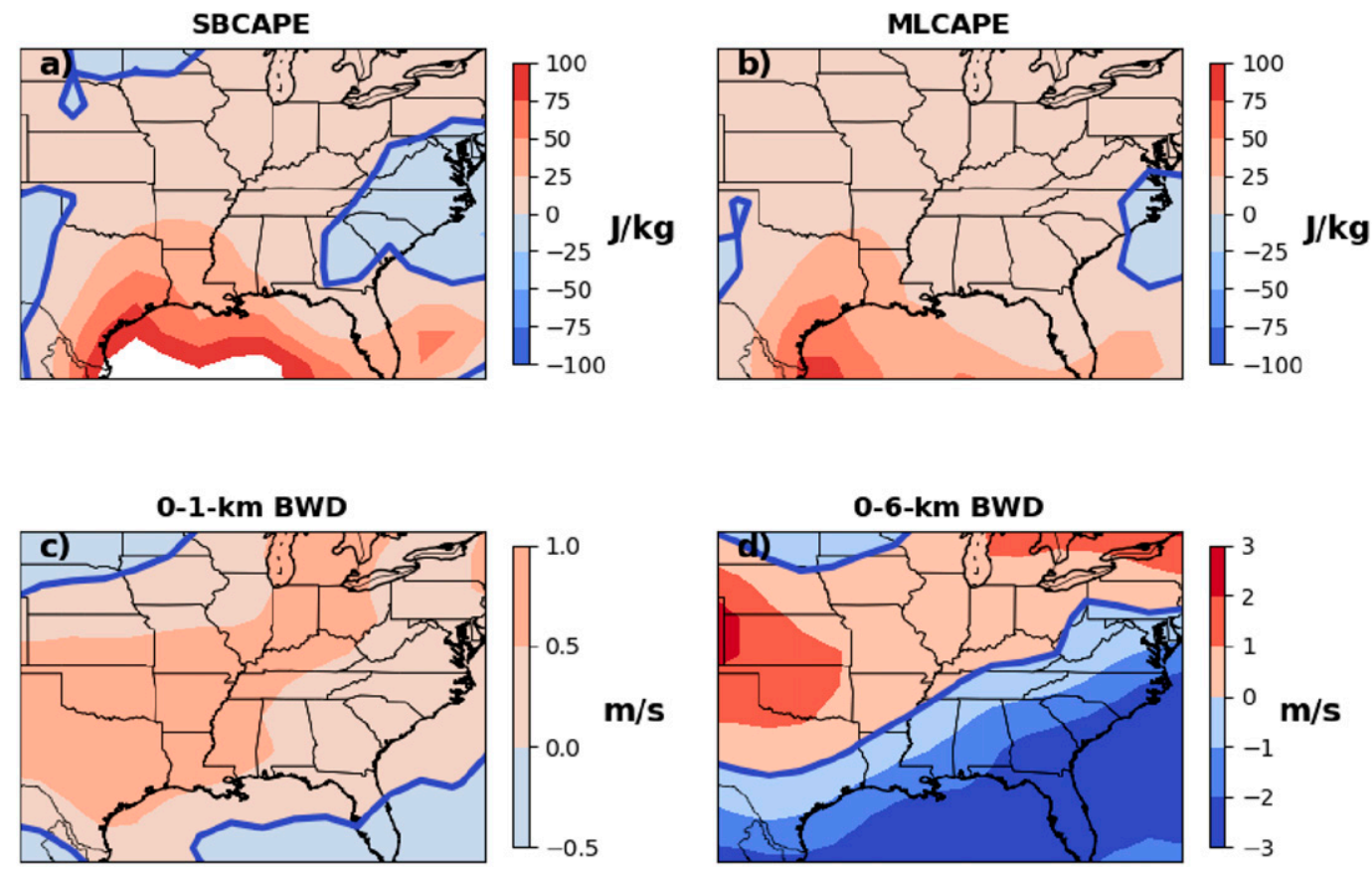

FIG. 9. Difference in 6-hourly mean NDJF (a) SBCAPE, (b) MLCAPE, (c) 0-1-km BWD, and (d) 0-6-km BWD for the most-tornadic - least-tornadic cold seasons. 

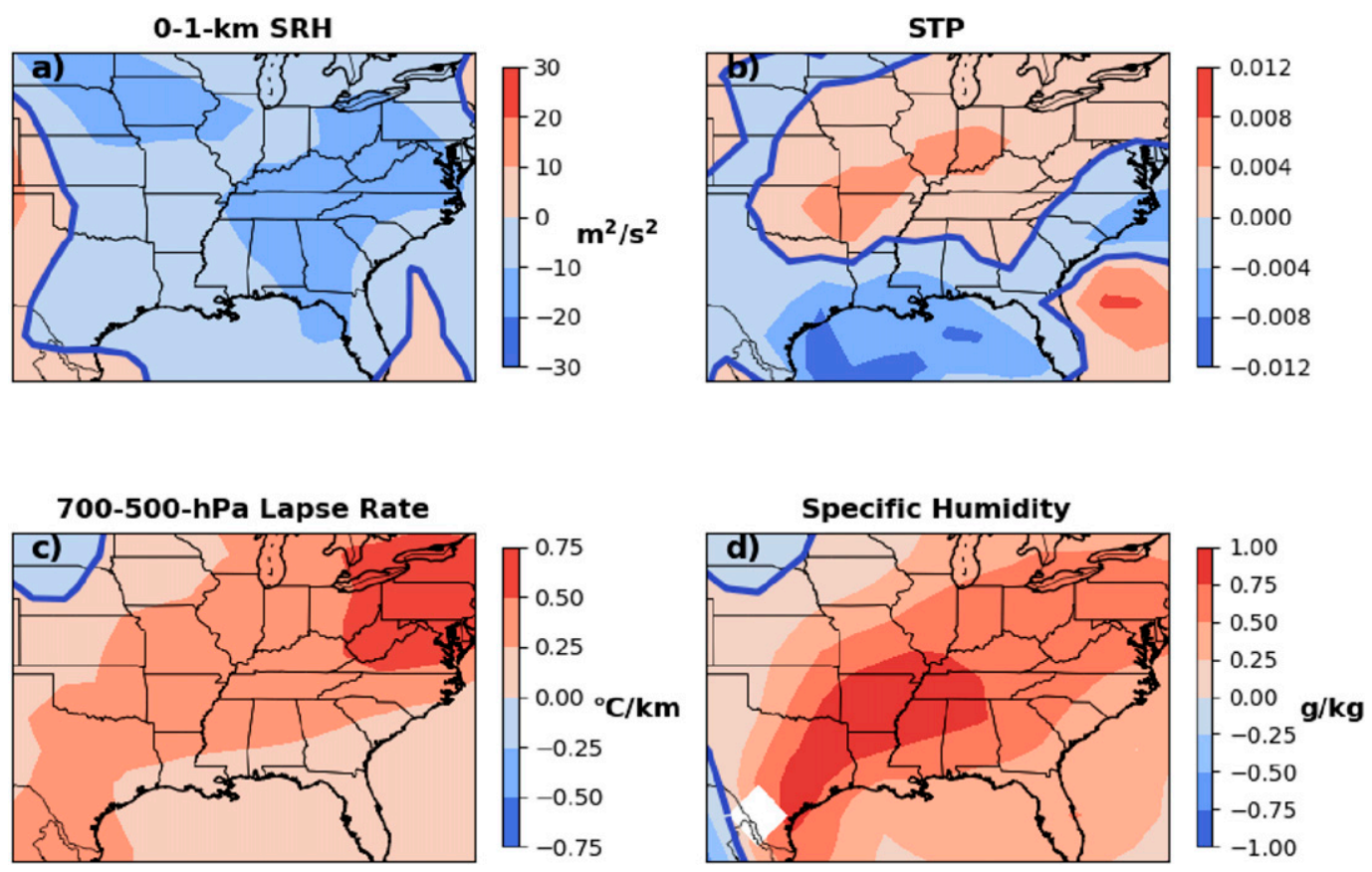

FIG. 10. Difference in 6-hourly mean NDJF values of (a) 0-1-km SRH, (b) STP, (c) 700-500-hPa lapse rate, and (d) mixed-layer specific humidity for the most-tornadic - least-tornadic cold seasons.

which a variable exceeds a threshold. To do this, thresholds representative of typical severe weather environments (as documented by SPC; http://www.spc.noaa.gov/ sfctest/help/sfcoa.html), were defined for each variable of interest, and the number of 6-hourly observations exceeding that threshold was compared for the 10 mosttornadic and 10 least-tornadic seasons. Table 6 shows these results for several variables, and Fig. 11 gives a spatial representation of four variables that by a test of independent proportions have significantly more observations exceeding their respective thresholds during most-tornadic seasons. Observations of SBCAPE and MLCAPE $>750 \mathrm{~J} \mathrm{~kg}^{-1}$ are more frequent in mosttornadic seasons and, for MLCAPE, the greatest spatial differences are found over the western GOM and Mississippi valley (Fig. 11a). Deep-layer shear does not discriminate between active and inactive seasons, but there are significantly more $0-1-\mathrm{km}$ BWD observations exceeding $20 \mathrm{~m} \mathrm{~s}^{-1}$ in the most-tornadic seasons. Spatially, the observations exceeding $20 \mathrm{~m} \mathrm{~s}^{-1}$ for both active and inactive seasons are located in the mid-Atlantic, not in the area of greatest NDJF tornado frequency (Fig. 11b). This could be explained by, for example, a nor'easter cyclone storm track providing observations of northerly $0-1-\mathrm{km}$ BWD in the mid-Atlantic or a large trough over the eastern United States with an associated surface low moving northeastward and generating large shear north of the warm front, displaced

TABLE 6. Counts of 6-hourly observations of a selected severe weather parameter (or combination of parameters) exceeding a threshold at any grid point within the domain during the 10 most-tornadic NDJF seasons and the 10 least-tornadic NDJF seasons. There are 921984 total observations for both the most-tornadic and least-tornadic seasons.

\begin{tabular}{|c|c|c|c|}
\hline & $0-1-\mathrm{km}$ shear $>20 \mathrm{~m} \mathrm{~s}^{-1}$ & $0-6-\mathrm{km}$ shear $>30 \mathrm{~m} \mathrm{~s}^{-1}$ & $0-1-\mathrm{km} \mathrm{SRH}>250 \mathrm{~m}^{2} \mathrm{~s}^{-2}$ \\
\hline Most tornadic & 5409 & 267314 & 58413 \\
\hline \multirow[t]{2}{*}{ Least tornadic } & 3291 & 281289 & 59990 \\
\hline & $\mathrm{SBCAPE}>750 \mathrm{~J} \mathrm{~kg}^{-1}$ & MLCAPE $>750 \mathrm{~J} \mathrm{~kg}^{-1}$ & $\mathrm{STP}>1.0$ \\
\hline Most tornadic & 39158 & 16456 & 532 \\
\hline \multirow[t]{2}{*}{ Least tornadic } & 30926 & 10220 & 354 \\
\hline & $\begin{array}{l}\text { 700-500-hPa lapse rate } \\
\quad>7 \mathrm{~K} \mathrm{~km}^{-1}\end{array}$ & $\begin{array}{c}\mathrm{SBCAPE}> \\
>750 \mathrm{~J} \mathrm{~kg}^{-1}+0-6-\mathrm{km}^{-1} \text { shear } \\
>30 \mathrm{~m} \mathrm{~s}^{-1}\end{array}$ & $\begin{array}{c}\text { MLCAPE }>750 \mathrm{~J} \mathrm{~kg}^{-1}+0-6-\mathrm{km}^{-1} \text { shear } \\
>30 \mathrm{~m} \mathrm{~s}^{-1}\end{array}$ \\
\hline Most tornadic & 159877 & 1233 & 415 \\
\hline Least tornadic & 121740 & 974 & 220 \\
\hline
\end{tabular}


a) MLCAPE

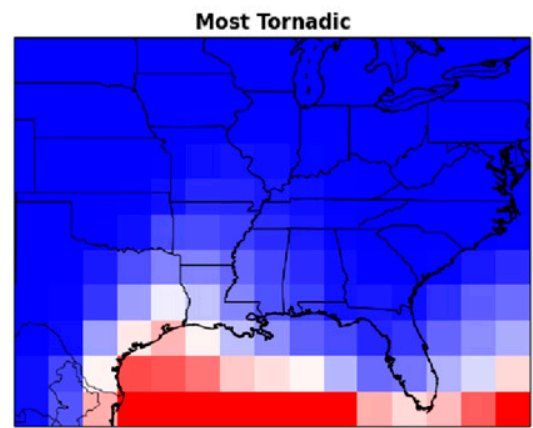

Least Tornadic

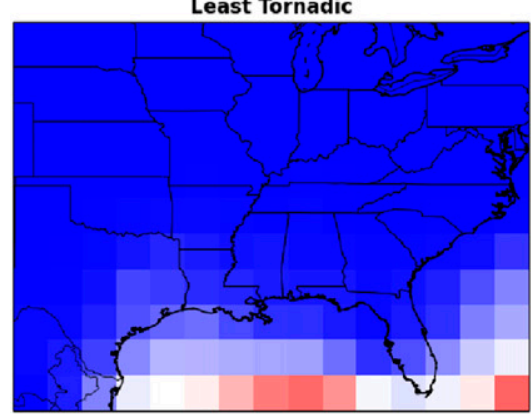

c) MLCAPE \& 0-6-km BWD

Most Tornadic

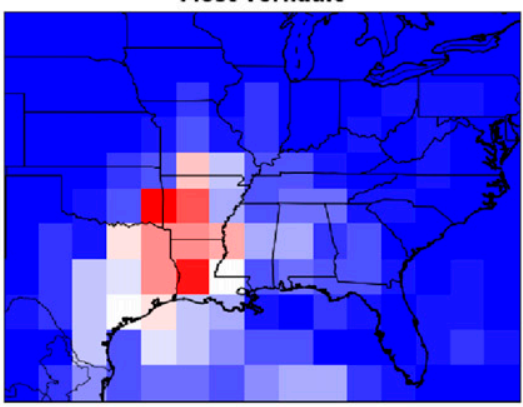

Least Tornadic
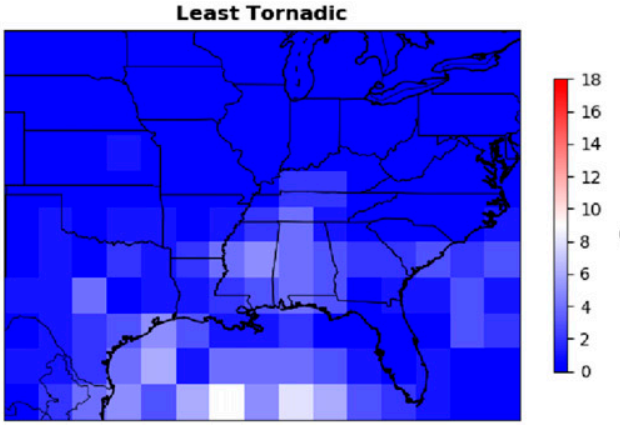

b) 0-1-km BWD

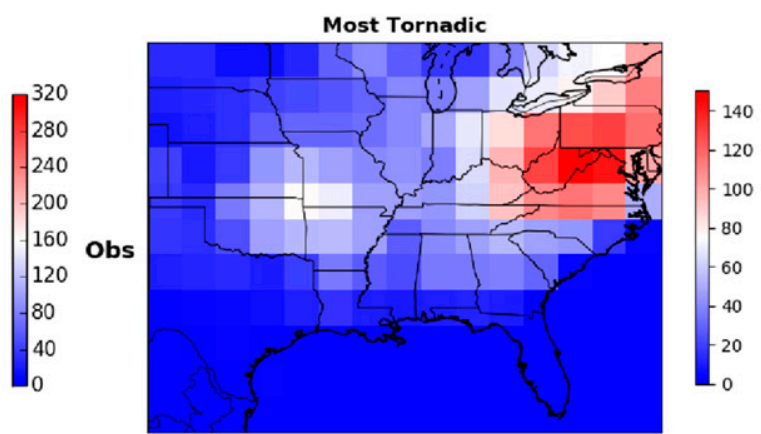

Obs

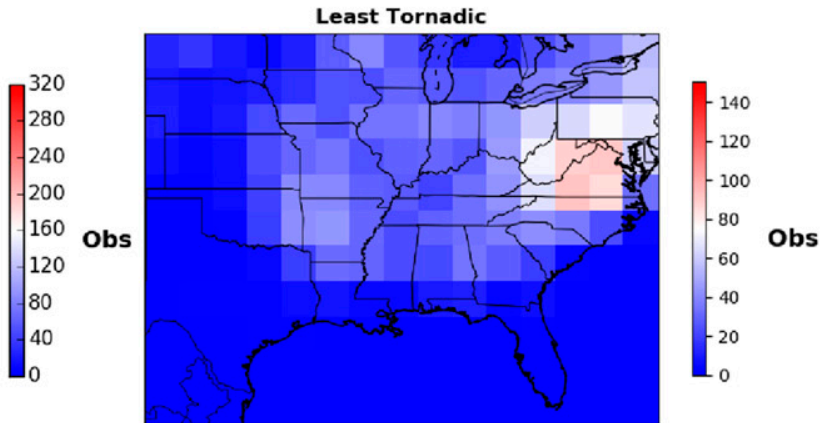

d) STP

Most Tornadic
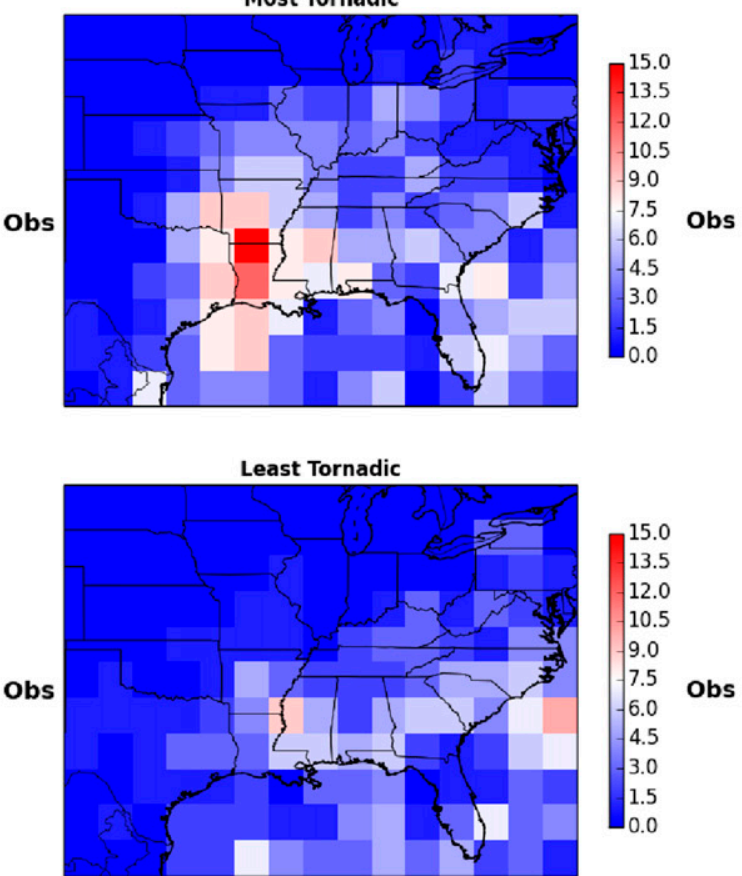

FIG. 11. Number of 6-hourly observations exceeding the following thresholds for the most-tornadic and leasttornadic seasons: (a) MLCAPE $>750 \mathrm{~J} \mathrm{~kg}^{-1}$, (b) 0-1-km BWD $>20 \mathrm{~m} \mathrm{~s}^{-1}$, (c) MLCAPE $>750 \mathrm{~J} \mathrm{~kg}^{-1}$ and 0-6-km BWD $>30 \mathrm{~m} \mathrm{~s}^{-1}$, and (d) STP $>1.0$. 

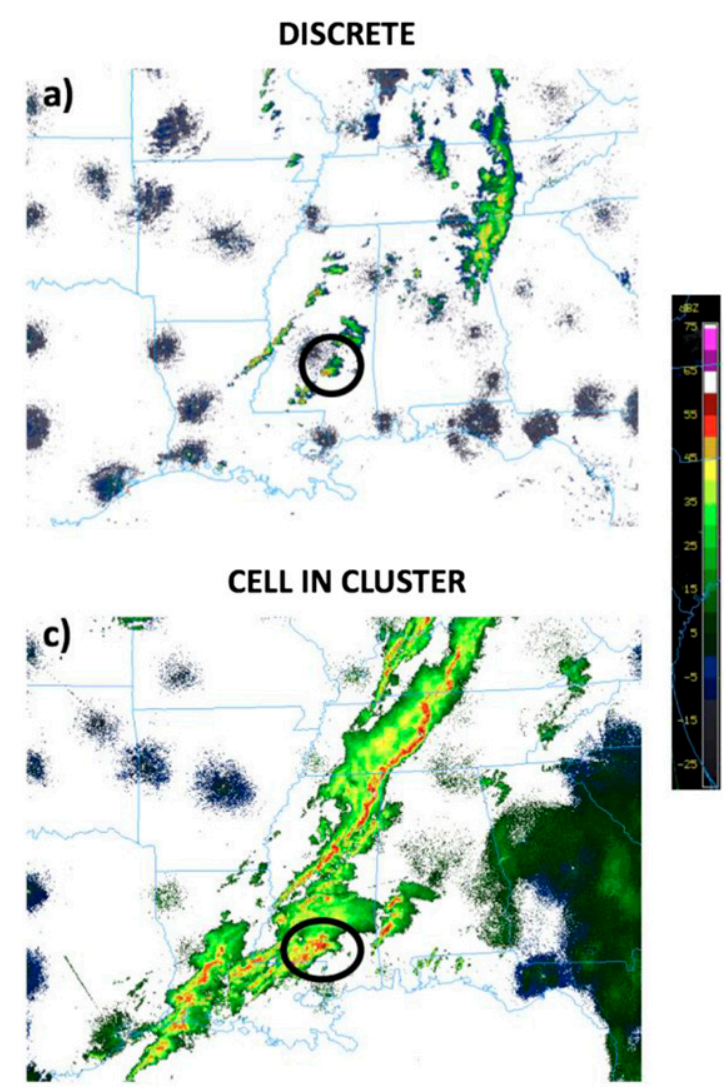
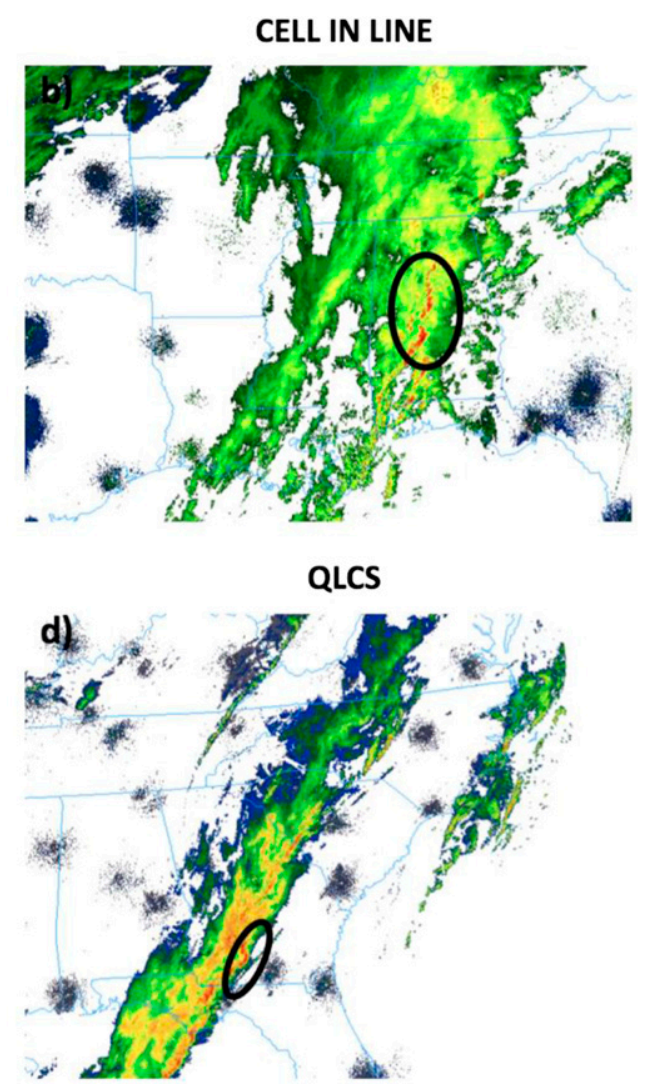

FIG. 12. Examples of radar imagery of each of the four storm modes defined in the SPC Storm Mode database, namely (a) discrete, 15 Dec 2014; (b) cell in line, 22 Dec 2011; (c) cell in cluster, 21 Feb 2014; and (d) QLCS, 4 Jan 2015. Examples are selected from the months of NDJF. Images are taken from NCAR's Mesoscale and Microscale Meteorology Laboratory (MMM) archives (http://www2.mmm.ucar.edu/imagearchive/).

from the CAPE farther south. While not common, concurrent observations of MLCAPE $>750 \mathrm{~J} \mathrm{~kg}^{-1}$ and $0-6-\mathrm{km} \mathrm{BWD}>30 \mathrm{~m} \mathrm{~s}^{-1}$ are significantly higher during tornadic seasons and spatially found inland of the western GOM (Fig. 11c), again showing the importance of advection of moisture-rich air from a warmer GOM in promoting favorable NDJF tornado environments. Similarly, there are statistically significantly more observations of STP $>1.0$ during the 10 most-tornadic seasons, again confined to the Mississippi valley region (Fig. 11d). Although the number of enhanced CAPE (and therefore STP) observations in NDJF pales in comparison to those during the warm season, it is noted that concurrent increased CAPE and high 0-6-km BWD need not last very many hours to produce tornadoes during the winter and may be poorly captured by the available diurnal analyses of the reanalysis. These results also confirm that combinations of ingredients (e.g., MLCAPE and 0-6-km BWD) or composite indices such as STP can produce very different patterns than when ingredients are considered separately (Johns et al. 1993).

\section{b. Storm mode}

It is also of interest to assess the convective modes of cold-season tornadoes to see if one particular mode dominates during NDJF. To do so, the SPC Storm Mode database was used (Smith et al. 2012; Thompson et al. 2012). This database contains convective mode classification and values of meteorological parameters for U.S. severe wind, hail, and tornado reports between 2003 and 2015. At the broadest level, severe reports are assigned to one of four convective mode bins: discrete, cell in line, cell in cluster, and quasi-linear convective system (QLCS). Examples of each convective mode, using actual NDJF tornadoes in the Storm Mode database, are presented in Fig. 12. The dataset was parsed in this study to classify all tornadoes of EF1+ intensity occurring during NDJF over the study domain. A few tornadoes that either were not assigned one of these four main modes or were missing classification altogether were excluded, yielding 1107 tornadoes for analysis. Previous results using this database showed that the southern United States has the greatest variability of tornado 
TABLE 7. Total count, average values of selected severe weather parameters, mean EF-scale rating, and total deaths for each of four convective mode categories as defined in the SPC Storm Mode database for NDJF tornadoes during the period 2003-15 within the study domain $\left(25^{\circ}-42.5^{\circ} \mathrm{N}, 75^{\circ}-100^{\circ} \mathrm{W}\right)$.

\begin{tabular}{|c|c|c|c|c|}
\hline & Discrete & Cell in line & Cell in cluster & QLCS \\
\hline Total count & 211 & 311 & 278 & 293 \\
\hline STP & 2.75 & 2.36 & 2.61 & 1.66 \\
\hline $\operatorname{SBCAPE}\left(\mathrm{J} \mathrm{kg}^{-1}\right)$ & 899 & 477 & 741 & 299 \\
\hline $0-6-\mathrm{km}$ shear $\left(\mathrm{m} \mathrm{s}^{-1}\right)$ & 30.2 & 31.7 & 30.2 & 32.5 \\
\hline $0-1-\mathrm{km}$ SRH $\left(\mathrm{m}^{2} \mathrm{~s}^{-2}\right)$ & 344.6 & 397.7 & 348.7 & 416.6 \\
\hline 700-500-hPa lapse $\left(\mathrm{K} \mathrm{km}^{-1}\right)$ & 6.36 & 6.16 & 6.13 & 5.90 \\
\hline EF-scale rating & 1.69 & 1.47 & 1.61 & 1.21 \\
\hline Total deaths & 76 & 50 & 73 & 6 \\
\hline
\end{tabular}

storm mode throughout the year (Smith et al. 2012). This is important since tornado-producing environments can look different based on storm mode. For example, Thompson et al. (2012) found that $75 \%$ of all wintertime QLCS tornadoes have MLCAPE $<450 \mathrm{~J} \mathrm{~kg}^{-1}$, but $75 \%$ of wintertime significant tornadoes from right-moving supercells have MLCAPE $>350 \mathrm{~J} \mathrm{~kg}^{-1}$.

Table 7 reveals that NDJF tornadoes occur in each storm mode. The smallest number of NDJF tornadoes spawn from discrete cells, yet still over 200 such cases have occurred since 2003 . The relatively balanced distribution in NDJF tornado storm modes confirms the assertion by Smith et al. (2012) of the high variability of storm mode in the southern United States and adds to the NDJF tornado forecasting complexity. Values of numerous convective parameters by storm mode (Table 7) were calculated to the nearest hour based on SPC mesoanalysis procedures (Thompson et al. 2012). Discrete and cell in cluster modes are associated with the highest STP, SBCAPE, EF-scale rating, and fatalities, while the QLCS mode had the lowest CAPE, EF-scale rating, and fatalities yet the highest mean shear, in accord with annual results from Thompson et al. (2012). This places a high importance on forecasters to accurately predict the mode of convection and communicate the risk to the public, since a much greater societal risk exists for NDJF tornadoes under the discrete and cell in cluster modes, whereas QLCS tornadoes are associated with fewer fatalities in wintertime.

The Storm Mode database also facilitates a comparison of average values of parameters for NDJF versus annual tornadoes. While Table 7 showcased CAPE and shear variables, Table 8 presents a wider suite of 16 parameters averaged across all NDJF and annual EF1+ tornadoes within the study domain. The associated Fig. 13 presents box-and-whisker plots of nine of these parameters for NDJF versus annual time periods. Consistent with previous findings here and from other work by Sherburn et al. (2016) and Cohen et al. (2017), a
low-CAPE-high-shear signal emerges for the NDJF tornado set, with average MLCAPE and SBCAPE some $600 \mathrm{~J} \mathrm{~kg}^{-1}$ less and mean shear variables $6-7 \mathrm{~m} \mathrm{~s}^{-1}$ greater in NDJF tornado environments compared to those of annual tornadoes. Figures $13 a-e$ also reveal that the spread for CAPE and shear variables for the NDJF dataset is much less than for the annual dataset, as it is for all variables displayed aside from $0-1-\mathrm{km}$ SRH (Fig. 13f). That NDJF tornado environments are characterized by warm and moist conditions is also affirmed, as the means (Table 8) and medians (Figs. 13g-i) of surface temperature and moisture variables for NDJF tornadoes are either comparable to or exceed those of annual tornadoes. Further, surface moisture rarely is lacking in NDJF tornadoes, as three-quarters of the tornado events had surface relative humidity values greater than $65 \%$ (Fig. 13h).

TABLE 8. Average values of severe weather and meteorological parameters for NDJF and annual (E)F1+ tornadoes in the SPC Storm Mode database (2003-15) within the study domain $\left(25^{\circ}-42.5^{\circ} \mathrm{N}\right.$, $\left.75^{\circ}-100^{\circ} \mathrm{W}\right)$. The respective sample sizes for the NDJF and annual tornadoes used in these calculations are 1107 and 4424.

\begin{tabular}{|c|c|c|}
\hline & NDJF & Annual \\
\hline STP & 2.6 & 3.6 \\
\hline $\operatorname{MLCAPE}\left(\mathrm{J} \mathrm{kg}^{-1}\right)$ & 561.6 & 1141.0 \\
\hline $\operatorname{SBCAPE}\left(\mathrm{J} \mathrm{kg}^{-1}\right)$ & 575.7 & 1271.3 \\
\hline MLLCL (m) & 676.6 & 824.2 \\
\hline $0-6-\mathrm{km}$ shear $\left(\mathrm{m} \mathrm{s}^{-1}\right)$ & 31.3 & 27.4 \\
\hline $0-1-\mathrm{km}$ shear $\left(\mathrm{m} \mathrm{s}^{-1}\right)$ & 20.1 & 16.8 \\
\hline Effective shear $\left(\mathrm{m} \mathrm{s}^{-1}\right)$ & 26.7 & 24.5 \\
\hline $0-3-\mathrm{km} \mathrm{SRH}\left(\mathrm{m}^{2} \mathrm{~s}^{-2}\right)$ & 440.6 & 388.4 \\
\hline $0-1-\mathrm{km}$ SRH $\left(\mathrm{m}^{2} \mathrm{~s}^{-2}\right)$ & 380.6 & 314.0 \\
\hline $0-3-\mathrm{km}$ lapse rate $\left(\mathrm{K} \mathrm{km}^{-1}\right)$ & 5.68 & 5.84 \\
\hline $700-500-\mathrm{hPa}$ lapse rate $\left(\mathrm{K} \mathrm{km}^{-1}\right)$ & 6.32 & 6.45 \\
\hline $850-500-\mathrm{hPa}$ lapse rate $\left(\mathrm{K} \mathrm{km}^{-1}\right)$ & 6.1 & 6.2 \\
\hline Surface temperature $\left[{ }^{\circ} \mathrm{C}\left({ }^{\circ} \mathrm{F}\right)\right]$ & $19.5(67.1)$ & $22.3(72.1)$ \\
\hline Surface dewpoint $\left[{ }^{\circ} \mathrm{C}\left({ }^{\circ} \mathrm{F}\right)\right]$ & $16.8(62.2)$ & $18.7(65.7)$ \\
\hline Surface RH (\%) & 85.1 & 81.2 \\
\hline PWAT [cm (in.)] & $3.63(1.43)$ & $3.96(1.56)$ \\
\hline
\end{tabular}



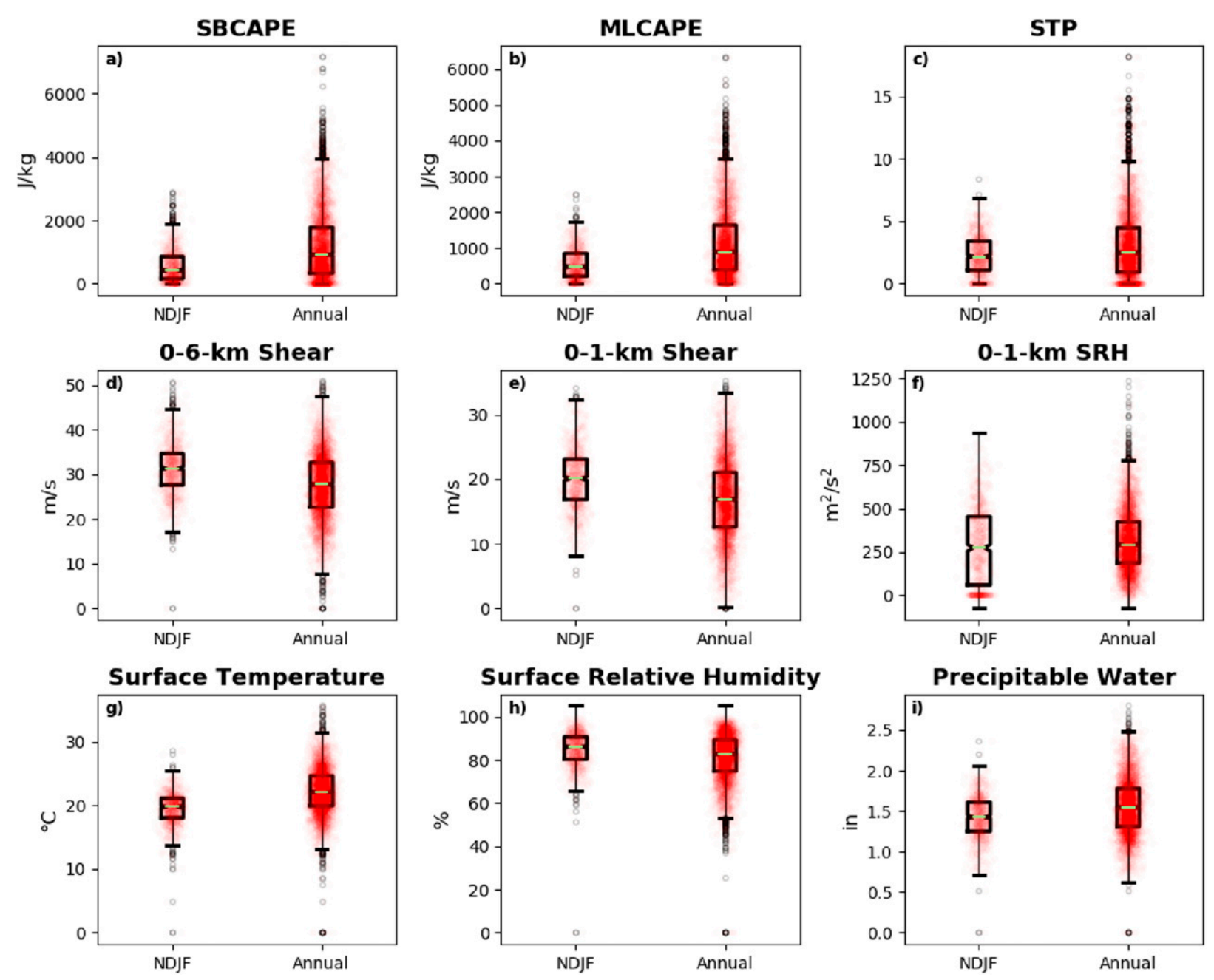

FIG. 13. Box-and-whisker plot of severe weather parameters in the Storm Mode database for all NDJF and annual (E)F1+ tornadoes within the study domain for the period 2003-15.

\section{Summary and conclusions}

Although tornado activity is least common during the cold season, significant events do happen in the wintertime that bring enhanced human vulnerability (Simmons and Sutter 2007; Ashley et al. 2008; Emrich and Cutter 2011). To help improve our understanding of cold-season events, this study has established a climatology of (E)F1(E)F5 tornadoes occurring in NDJF across the domain of $25^{\circ}-42.5^{\circ} \mathrm{N}, 75^{\circ}-100^{\circ} \mathrm{W}$ over the period $1953-2015$. Linear regression performed over the domain on a $2.5^{\circ} \times 2.5^{\circ}$ grid reveals a significant increasing trend in NDJF counts in the Mississippi valley region, with a bull's-eye across central and western Tennessee. Given that this region has one of the highest societal vulnerabilities in the country (Ashley et al. 2008; Emrich and Cutter 2011; Ashley and Strader 2016), an increase in cold-season tornado activity poses many risks (Childs and Schumacher 2018) and warrants investigation into potential meteorological influences. Conversely, eastern Oklahoma shows a significantly decreasing trend in NDJF counts over the past 62 seasons. The spatial pattern of these trends aligns with the spatial shift in annual tornado activity (Agee et al. 2016).

The creation of power spectra of tornado time series, a technique with only limited use in tornado studies ( $\mathrm{Lu}$ et al. 2015), reveals an oscillating 3-7-yr cycle of enhanced NDJF tornado counts. This period is the same as that of ENSO, and it is found that during La Niña winters, NDJF tornadoes are more common, consistent with past studies. An even stronger relationship exists between NDJF tornado counts and the Arctic Oscillation. When the AO is positive, a stronger polar jet tends to confine colder air to the Arctic, allowing for substantially more NDJF tornadoes in the southeastern United States. It is important to note that although significant, the correlations between these teleconnection 
indices and NDJF tornado counts are fairly weak; however, this study adds to the growing body of work attempting to use teleconnections to develop seasonal forecasts of tornadoes (e.g., Allen et al. 2015; Gensini and Marinaro 2016; Sparrow and Mercer 2016; Lepore et al. 2017), in this case suggesting predictability for an upcoming cold season. The obvious barrier is the ability to predict these teleconnections months in advance; for example, the AO can oscillate between phases on a monthly and even weekly basis. Yet, as our understanding improves, one could envision a seasonal probabilistic forecast for NDJF tornadoes issued in summer or fall, which would serve to heighten public awareness and help city officials and emergency managers to budget for resource allocation. In addition, the findings herein could contribute to more skillful monthly or weeks 2-4 probabilistic forecasts for tornadoes. Investigation of additional teleconnection patterns would add even more opportunities for advancement in seasonal forecasting.

Monthly and 6-hourly meteorological variables from the NCEP-NCAR reanalysis were averaged over NDJF to give a general representation of environments that favor tornadic cold seasons. From a synoptic perspective, seasons of enhanced NDJF tornado activity are characterized by a mean trough in the West and a ridge in the East, with an upper-level jet streak across the plains. These features favor convection and potential severe weather near the Mississippi valley region, downstream of the trough axis, where indeed most NDJF tornadoes occur and are increasing. Higher 500-hPa heights over the East and lower 500-hPa heights over the North Atlantic during most-tornadic seasons suggest a positive AO pattern, which confirms its association with NDJF tornadoes.

One of the strongest discriminators between the mosttornadic and least-tornadic cold seasons was found to be low-level moisture. Compared to least-tornadic seasons, most-tornadic seasons are characterized by up to an $8 \%$ greater mean surface relative humidity, greater PWAT, and higher mixed-layer specific humidity. Moreover, the average dewpoint temperatures reported in the Storm Mode database (2003-15), which are taken from the nearest reporting station at the time closest to tornado occurrence, do not differ much for NDJF versus annual (E)F1-(E)F5 tornadoes $\left[16.8^{\circ} \mathrm{C}\left(62.2^{\circ} \mathrm{F}\right)\right.$ vs $18.7^{\circ} \mathrm{C}$ $\left.\left(65.8^{\circ} \mathrm{F}\right)\right]$. Spatially, moisture in most-tornadic seasons is enhanced along a southwest-to-northeast swath across the South and Mississippi valley. Gulf of Mexico SSTs may help explain this pattern. A dipole exists between warmer-than-average western GOM waters and coolerthan-average eastern GOM waters during most-tornadic seasons, which may be driving warm and moisture-rich air into Texas and Louisiana, which is subsequently advected northeastward by the mean flow. The reason why the western (eastern) GOM is warmer (cooler) during mosttornadic seasons is not entirely clear, but the link between moisture advection from the western GOM and NDJF tornado activity does not seem to be coincidental. In fact, early analysis of cold-season tornadoes by Galway and Pearson (1981) showed a similar association between cold-season tornado outbreaks and the transport of lowlevel moisture from the GOM north and east, which helps to saturate an otherwise dry environment (see also Guyer et al. 2006).

Given that low-level moisture may be an important driver for tornadic cold seasons in the Southeast, it is also of worth to assess the interplay between buoyancy and vertical wind shear. It has been shown that a lowCAPE-high-shear signal exists in wintertime severe weather environments (Davies 2006; Guyer et al. 2006; Schneider et al. 2006; Brooks 2009; Sherburn and Parker 2014; Sherburn et al. 2016; King et al. 2017), and the climatology established here confirms this. Given the strong wintertime upper-level jet stream and frequent passage of extratropical cyclones, 6-hourly 0-6-km BWD observations exceeding $30 \mathrm{~m} \mathrm{~s}^{-1}$ are common in both the most-tornadic and least-tornadic seasons and are spatially most pronounced in the mid-Atlantic, displaced from where most NDJF tornado activity occurs. Very few 6-hourly observations of MLCAPE exceed $750 \mathrm{~J} \mathrm{~kg}^{-1}$ in the NDJF record, yet significantly more of these instances exist during active seasons. Therefore, although vertical wind shear is not a good discriminator of NDJF tornado activity (because wind fields are already stronger than at other times of year), when sufficient CAPE exists (even for a short amount of time), the environment rapidly becomes much more favorable for tornadoes (King et al. 2017). Indeed, there are significantly more 6-hourly observations of MLCAPE $>750 \mathrm{~J} \mathrm{~kg}^{-1}+$ $0-6-\mathrm{km} \mathrm{BWD}>30 \mathrm{~m} \mathrm{~s}^{-1}$ in most-tornadic seasons compared to least-tornadic seasons. Additionally, cold-season tornado environments tend to be characterized by steeper-than-average $700-500-\mathrm{hPa}$ lapse rates, which is an indicator of amplified instability. SRH, like vertical wind shear, already is enhanced in the winter and thus is not found to discriminate between the most-tornadic and least-tornadic cold seasons. To summarize, coldseason tornadoes tend to occur under anomalously warm surface temperatures, very moist low levels, enhanced wind shear, and low CAPE, usually coupled with an upper-level trough and jet streak west of the activity.

Finally, convective modes of NDJF tornadoes were analyzed from the SPC Storm Mode database. Tornado activity is not significantly favored under one particular mode; rather, over 200 reports of tornadoes exist for each of the four main modes. However, there is much greater risk for death and injury from discrete-cell 
NDJF tornadoes, and these tornadoes also are stronger than those from a QLCS. Future research toward developing predictive skill for convective mode is warranted, as a better forecast of the expected storm mode could alter the impact message that is communicated to the public. The 13-yr record contained in the SPC Storm Mode database also confirms the low-CAPE-high-shear signature in NDJF tornado environments seen here and in previous work (Davies 2006; Guyer et al. 2006; Schneider et al. 2006; Sherburn and Parker 2014; Sherburn et al. 2016).

While there are undoubtedly more connections to be made between NDJF tornadoes and other severe weather parameters or teleconnections, the analysis presented here reveals some new relationships that can be of value to the meteorological community. As potential for major cold-season tornado events persists and potentially rises, the findings conveyed here can serve to more effectively communicate risk and warning messages to the public, thereby increasing public awareness and helping to mitigate potentially damaging societal impacts.

Acknowledgments. This material is based upon work supported by the National Science Foundation Graduate Research Fellowship Program under Grant DGE1321845, and NOAA Grants NA15OAR4590233 and NA16OAR4590215. Any opinions, findings, and conclusions or recommendations expressed in this material are those of the author and do not necessarily reflect the views of the National Science Foundation. The authors also thank Bryan Smith from SPC for allowing access to the Storm Mode database. The authors are also grateful for Jon Davies and two additional anonymous reviewers for providing helpful comments and suggestions to improve the original manuscript.

\section{REFERENCES}

Agee, E. M., and S. J. Childs, 2014: Adjustments in tornado counts, F-scale intensity, and path width for assessing significant tornado destruction. J. Appl. Meteor. Climatol., 53, 1494-1505, https://doi.org/10.1175/JAMC-D-13-0235.1.

— , J. Larson, S. J. Childs, and A. Marmo, 2016: Spatial redistribution of U.S. tornado activity between 1954 and 2013. J. Appl. Meteor. Climatol., 55, 1681-1697, https://doi.org/ 10.1175/JAMC-D-15-0342.1.

Allan, R. J., 1999: ENSO and climatic variability in the last 150 years. El Niño and the Southern Oscillation: Multiscale Variability and Its Impact on Natural Ecosystems and Society, H. F. Diaz and V. Markgraf, Eds., Cambridge University Press, 3-54.

Allen, J. T., M. K. Tippett, and A. H. Sobel, 2015: Influence of the El Niño/Southern Oscillation on tornado and hail frequency in the United States. Nat. Geosci., 8, 278-283, https://doi.org/ 10.1038/ngeo2385.
Anderson, C. J., C. K. Wikle, Q. Zhou, and J. A. Royle, 2007: Population influences on tornado reports in the United States. Wea. Forecasting, 22, 571-579, https://doi.org/10.1175/WAF997.1.

Ashley, W. S., 2007: Spatial and temporal analysis of tornado fatalities in the United States: 1880-2005. Wea. Forecasting, 22, 1214-1228, https://doi.org/10.1175/2007WAF2007004.1.

_ , and S. M. Strader, 2016: Recipe for disaster: How the dynamic ingredients of risk and exposure are changing the tornado disaster landscape. Bull. Amer. Meteor. Soc., 97, 767786, https://doi.org/10.1175/BAMS-D-15-00150.1.

_ A. J. Krmenec, and R. Schwantes, 2008: Vulnerability due to nocturnal tornadoes. Wea. Forecasting, 23, 795-807, https:// doi.org/10.1175/2008WAF2222132.1.

Brooks, H. E., 2009: Proximity soundings for severe convection for Europe and the United States from reanalysis data. Atmos. Res., 93, 546-553, https://doi.org/10.1016/j.atmosres.2008.10.005.

, J. W. Lee, and J. P. Craven, 2003: The spatial distribution of severe thunderstorm and tornado environments from global reanalysis data. Atmos. Res., 67-68, 73-94, https://doi.org/ 10.1016/S0169-8095(03)00045-0.

— , G. W. Carbin, and P. T. Marsh, 2014: Increased variability of tornado occurrence in the United States. Science, 346, 349352, https://doi.org/10.1126/science.1257460.

Cheng, V. Y. S., G. B. Arhonditsis, D. M. L. Sills, W. A. Gough, and H. Auld, 2016: Predicting the climatology of tornado occurrences in North America with a Bayesian hierarchical modeling framework. J. Climate, 29, 1899-1917, https://doi.org/ 10.1175/JCLI-D-15-0404.1.

Childs, S. J., and R. S. Schumacher, 2018: Cold-season tornado risk communication: Case studies from November 2016-February 2017. Wea. Climate Soc., https://doi.org/10.1175/WCAS-D-170073.1, in press.

Clark, A. J., C. J. Schaffer, W. A. Gallus Jr., and K. JohnsonO'Mara, 2009: Climatology of storm reports relative to upperlevel jet streaks. Wea. Forecasting, 24, 1032-1051, https:// doi.org/10.1175/2009WAF2222216.1.

Cohen, A. E., S. M. Cavallo, M. C. Coniglio, and H. E. Brooks, 2015: A review of planetary boundary layer parameterization schemes and their sensitivity in simulating southeastern U.S. cold season severe weather environments. Wea. Forecasting, 30, 591-612, https://doi.org/10.1175/WAF-D-14-00105.1.

,,,$----\longrightarrow$, and I. L. Jirak, 2017: Evaluation of multiple planetary boundary layer parameterization schemes in Southeast U.S. cold season severe thunderstorm environments. Wea. Forecasting, 32, 1857-1884, https://doi.org/ 10.1175/WAF-D-16-0193.1.

Cook, A. R., and J. T. Schaefer, 2008: The relation of El NiñoSouthern Oscillation (ENSO) to winter tornado outbreaks. Mon. Wea. Rev., 136, 3121-3137, https://doi.org/10.1175/ 2007MWR2171.1.

— L. M. Leslie, D. B. Parsons, and J. T. Schaefer, 2017: The impact of the El Niño-Southern Oscillation (ENSO) on winter and early spring U.S. tornado outbreaks. J. Appl. Meteor. Climatol., 56, 2455-2478, https://doi.org/10.1175/JAMC-D-16-0249.1.

CPC, 2012: AAO, AO, NAO, PNA. Climate Prediction Center, http:// www.cpc.ncep.noaa.gov/products/precip/CWlink/daily_ao_index/ teleconnections.shtml.

Craven, J. P., 2000: A preliminary look at deep layer shear and middle level lapse rates associated with major tornado outbreaks. Preprints, 20th Conf. on Severe Local Storms, Orlando, FL, Amer. Meteor. Soc., 547-550. 
Cutter, S. L., B. J. Boruff, and W. L. Shirley, 2003: Social vulnerability to environmental hazards. Soc. Sci. Quart., 84, 242-261, https://doi.org/10.1111/1540-6237.8402002.

Davies, J. M., 2006: RUC soundings with cool season tornadoes in "small" CAPE settings and the 6 November 2005 Evansville, Indiana tornado. 23rd Conf. on Severe Local Storms, St. Louis, MO, Amer. Meteor. Soc., 4.3, https://ams.confex.com/ams/ pdfpapers/115477.pdf.

—, and A. Fischer, 2009: Environmental characteristics associated with nighttime tornadoes. Electron. J. Oper. Meteor., 10, 2009-EJ3, http://www.nwas.org/ej/pdf/2009-EJ3.pdf.

Diffenbaugh, N. S., M. Scherer, and R. J. Trapp, 2013: Robust increases in severe thunderstorm environments in response to greenhouse forcing. Proc. Natl. Acad. Sci. USA, 110, 1636116366, https://doi.org/10.1073/pnas.1307758110.

Doswell, C. A., III, and D. W. Burgess, 1988: On some issues of United States tornado climatology. Mon. Wea. Rev., 116, 495-501, https://doi.org/10.1175/1520-0493(1988)116<0495: OSIOUS $>2.0 . \mathrm{CO} ; 2$.

Edwards, R., and H. E. Brooks, 2010: Possible impacts of the enhanced Fujita scale on United States tornado data. 25th Conf. on Severe Local Storms, Denver, CO, Amer. Meteor. Soc., P.8.28, https://ams.confex.com/ams/pdfpapers/175398.pdf.

— J. G. LaDue, J. T. Ferree, K. Scharfenberg, C. Maier, and W. L. Coulbourne, 2013: Tornado intensity estimation: Past, present, and future. Bull. Amer. Meteor. Soc., 94, 641-653, https://doi.org/10.1175/BAMS-D-11-00006.1.

Elsner, J. B., L. E. Michaels, K. N. Scheitlin, and I. J. Elsner, 2013: The decreasing population bias in tornado reports across the central plains. Wea. Climate Soc., 5, 221-232, https://doi.org/ 10.1175/WCAS-D-12-00040.1.

— S. C. Elsner, and T. H. Jagger, 2015: The increasing efficiency of tornado days in the United States. Climate Dyn., 45, 651659, https://doi.org/10.1007/s00382-014-2277-3.

Emrich, C. T., and S. L. Cutter, 2011: Social vulnerability to climatesensitive hazards in the southern United States. Wea. Climate Soc., 3, 193-208, https://doi.org/10.1175/2011WCAS1092.1.

Farney, T. J., and P. G. Dixon, 2015: Variability of tornado climatology across the continental United States. Int. J. Climatol., 35, 2993-3006, https://doi.org/10.1002/joc.4188.

Galway, J. G., and A. Pearson, 1981: Winter tornado outbreaks. Mon. Wea. Rev., 109, 1072-1080, https://doi.org/10.1175/15200493(1981)109<1072:WTO>2.0.CO;2.

Gensini, V. A., and W. S. Ashley, 2011: Climatology of potentially severe convective environments from the North American Regional Reanalysis. Electron. J. Severe Storms Meteor., 6 (8), http://www.ejssm.org/ojs/index.php/ejssm/article/viewArticle/85.

- and A. Marinaro, 2016: Tornado frequency in the United States related to global relative angular momentum. Mon. Wea. Rev., 144, 801-810, https://doi.org/10.1175/MWR-D-15-0289.1.

Grams, J. S., R. L. Thompson, D. V. Snively, J. A. Prentice, G. M. Hodges, and L. J. Reames, 2012: A climatology and comparison of parameters for significant tornado events in the United States. Wea. Forecasting, 27, 106-123, https://doi.org/10.1175/ WAF-D-11-00008.1.

Guo, L., K. Wang, and H. B. Bluestein, 2016: Variability of tornado occurrence over the continental United States since 1950. J. Geophys. Res. Atmos., 121, 6943-6953, https://doi.org/ 10.1002/2015JD024465.

Guyer, J. L., and A. R. Dean, 2010: Tornadoes within weak CAPE environments across the continental United States. 25th Conf. on Severe Local Storms, Denver, CO, Amer.
Meteor. Soc., 1.5, https://ams.confex.com/ams/25SLS/techprogram/ paper_175725.htm.

- D. A. Imy, and A. K. Kis, 2006: Cool season significant (F2-F5) tornadoes in the Gulf Coast states. 23rd Conf. on Severe Local Storms, St. Louis, MO, Amer. Meteor. Soc., 4.2, https:// ams.confex.com/ams/23SLS/techprogram/paper_115320.htm.

Hales, J. E., Jr., and C. A. Doswell III, 1982: High-resolution diagnosis of instability using hourly surface-lifted parcel temperatures. Preprints, 12th Conf. on Severe Local Storms, San Antonio, TX, Amer. Meteor. Soc., 172-175.

Hanstrum, B. N., G. A. Mills, A. Watson, J. P. Monteverdi, and C. A. Doswell III, 2002: The cool-season tornadoes of California and southern Australia. Wea. Forecasting, 17, 705-722, https://doi. org/10.1175/1520-0434(2002)017<0705:TCSTOC >2.0.CO;2.

Hirahara, S., M. Ishii, and Y. Fukuda, 2014: Centennial-scale sea surface temperature analysis and its uncertainty. J. Climate, 27, 57-75, https://doi.org/10.1175/JCLI-D-12-00837.1.

Johns, R. H., J. M. Davies, and P. W. Leftwich, 1993: Some wind and instability parameters associated with strong and violent tornadoes. Part 2. Variations in the combinations of wind and instability parameters. The Tornado: Its Structure, Dynamics, Prediction, and Hazards, Geophys. Monogr., Vol. 79, Amer. Geophys. Union, 583-590.

Kalnay, E., and Coauthors, 1996: The NCEP/NCAR 40-Year Reanalysis Project. Bull. Amer. Meteor. Soc., 77, 437-471, https://doi. org/10.1175/1520-0477(1996)077<0437:TNYRP>2.0.CO;2.

King, J. R., M. D. Parker, K. D. Sherburn, and G. M. Lackmann, 2017: Rapid evolution of cool season, low-CAPE severe thunderstorm environments. Wea. Forecasting, 32, 763-778, https://doi.org/10.1175/WAF-D-16-0141.1.

Kis, A. K., and J. M. Straka, 2010: Nocturnal tornado climatology. Wea. Forecasting, 25, 545-561, https://doi.org/10.1175/ 2009WAF2222294.1.

Kounkou, R., G. Mills, and B. Timbal, 2009: A reanalysis climatology of cool-season tornado environments over southern Australia. Int. J. Climatol., 29, 2079-2090, https://doi.org/ 10.1002/joc.1856.

Lepore, C., M. K. Tippett, and J. T. Allen, 2017: ENSO-based probabilistic forecasts of March-May U.S. tornado and hail activity. Geophys. Res. Lett., 44, 9093-9101, https://doi.org/ 10.1002/2017GL074781.

Livingston, I., 2013: Largest tornado outbreaks in the United States. USTornadoes.com, http://www.ustornadoes.com/2013/ 01/21/largest-winter-tornado-outbreaks-in-the-united-states/.

Lu, M., M. Tippett, and U. Lall, 2015: Changes in the seasonality of tornado and favorable genesis conditions in the central United States. Geophys. Res. Lett., 42, 4224-4231, https://doi.org/ 10.1002/2015GL063968.

McCarthy, D., and J. T. Schaefer, 2004: Tornado trends over the past thirty years. 14th Conf. on Applied Meteorology, Seattle, WA, Amer. Meteor. Soc., 3.4, https://ams.confex.com/ams/ 84Annual/techprogram/paper_72089.htm.

Molina, M. J., R. P. Timmer, and J. T. Allen, 2016: Importance of the Gulf of Mexico as a climate driver for U.S. severe thunderstorm activity. Geophys. Res. Lett., 43, 12 295-12304, https://doi.org/10.1002/2016GL071603.

NCEI, 2017a: Historical records and trends. National Centers for Environmental Information, https://www.ncdc.noaa.gov/ climate-information/extreme-events/us-tornado-climatology/trends. 2017b: State of the climate: Tornadoes for January 2017 National Centers for Environmental Information, https:// www.ncdc.noaa.gov/sotc/tornadoes/201701. 
NSSL, 2017: NSSL research: Tornadoes. National Severe Storms Laboratory, http://www.nssl.noaa.gov/research/tornadoes/.

Nunn, K. H., and A. DeGaetano, 2004: The El Niño-Southern Oscillation and its role in cold-season tornado outbreak climatology. 15th Symp. on Global and Climate Change/14th Conf. on Applied Climatology, Seattle, WA, Amer. Meteor. Soc., JP5, https://ams.confex.com/ams/pdfpapers/71587.pdf.

NWS, 2009: Super Tuesday tornado outbreak of February 5-6, 2008. NWS Service Assessment, 48 pp., http://www.nws.noaa. gov/os/assessments/pdfs/super_tuesday.pdf.

Rasmussen, E. N., and D. O. Blanchard, 1998: A baseline climatology of sounding-derived supercell and tornado forecast parameters. Wea. Forecasting, 13, 1148-1164, https://doi.org/ 10.1175/1520-0434(1998)013<1148:ABCOSD > 2.0.CO;2.

Robinson, E. D., R. J. Trapp, and M. E. Baldwin, 2013: The geospatial and temporal distributions of severe thunderstorms from high-resolution dynamical downscaling. J. Appl. Meteor. Climatol., 52, 2147-2161, https://doi.org/10.1175/JAMC-D-120131.1.

Rose, S. F., P. V. Hobbs, J. D. Locatelli, and M. T. Stoelinga, 2004: A 10-yr climatology relating the locations of reported tornadoes to the quadrants of upper-level jet streaks. Wea. Forecasting, 19, 301-309, https://doi.org/10.1175/1520-0434(2004) $019<0301$ :AYCRTL > 2.0.CO;2.

Schaefer, J. T., and R. Edwards, 1999: The SPC tornado/severe thunderstorm database. Preprints, 11th Conf. on Applied Climatology, Dallas, TX, Amer. Meteor. Soc., 215-220.

Schneider, R. S., A. R. Dean, S. J. Weiss, and P. D. Bothwell, 2006: Analysis of estimated environments for 2004 and 2005 severe convective storm reports. 23rd Conf. Severe Local Storms, St. Louis MO, Amer. Meteor. Soc., 3.5, https://ams.confex.com/ ams/23SLS/techprogram/paper_115246.htm.

Sherburn, K. D., and M. D. Parker, 2014: Climatology and ingredients of significant severe convection in high-shear, lowCAPE environments. Wea. Forecasting, 29, 854-877, https:// doi.org/10.1175/WAF-D-13-00041.1.

_ _ _ _ J. R. King, and G. M. Lackmann, 2016: Composite environments of severe and nonsevere high-shear, low-CAPE convective events. Wea. Forecasting, 31, 1899-1927, https:// doi.org/10.1175/WAF-D-16-0086.1.

Simmons, K. M., and D. Sutter, 2007: The Groundhog Day Florida tornadoes: A case study of high-vulnerability tornadoes. Quick Response Research Rep. 193, Natural Hazards Research and Applications Information Center, University of Colorado Boulder, 10 pp., http:// hermes.cde.state.co.us/drupal/islandora/object/co \%3A5448.

Smith, B. T., R. L. Thompson, J. S. Grams, C. Broyles, and H. E. Brooks, 2012: Convective modes for significant severe thunderstorms in the contiguous United States. Part I: Storm classification and climatology. Wea. Forecasting, 27, 1114-1135, https://doi.org/10.1175/WAF-D-11-00115.1.
Sparrow, K. H., and A. E. Mercer, 2016: Predictability of US tornado outbreak seasons using ENSO and Northern Hemisphere geopotential height variability. Geosci. Front., 7, 21-31, https://doi.org/10.1016/j.gsf.2015.07.007.

Strader, S. M., W. Ashley, A. Irizarry, and S. Hall, 2015: A climatology of tornado intensity assessments. Meteor. Appl., 22, 513-524, https://doi.org/10.1002/met.1482.

Thompson, D. B., and P. E. Roundy, 2013: The relationship between the Madden-Julian oscillation and U.S. violent tornado outbreaks in the spring. Mon. Wea. Rev., 141, 2087-2095, https://doi.org/10.1175/MWR-D-12-00173.1.

Thompson, D. W. J., and J. M. Wallace, 1998: The Arctic Oscillation signature in the wintertime geopotential height and temperature fields. Geophys. Res. Lett., 25, 1297-1300, https:// doi.org/10.1029/98GL00950.

Thompson, R. L., R. Edwards, J. A. Hart, K. L. Elmore, and P. Markowski, 2003: Close proximity soundings within supercell environments obtained from the Rapid Update Cycle. Wea. Forecasting, 18, 1243-1261, https://doi.org/10.1175/15200434(2003)018<1243:CPSWSE $>2.0$.CO;2.

, C. M. Mead, and R. Edwards, 2007: Effective storm-relative helicity and bulk shear in supercell thunderstorm environments. Wea. Forecasting, 22, 102-115, https://doi.org/10.1175/ WAF969.1.

— B. B. Smith, J. S. Grams, A. R. Dean, and C. Broyles, 2012: Convective modes for significant severe thunderstorms in the contiguous United States. Part II: Supercell and QLCS tornado environments. Wea. Forecasting, 27, 1136-1154, https:// doi.org/10.1175/WAF-D-11-00116.1.

Tippett, M. K., 2014: Changing volatility of U.S. annual tornado reports. Geophys. Res. Lett., 41, 6956-6961, https://doi.org/ 10.1002/2014GL061347.

— A. A. Sobel, S. J. Camargo, and J. T. Allen, 2014: An empirical relation between U.S. tornado activity and monthly environmental parameters. J. Climate, 27, 2983-2999, https:// doi.org/10.1175/JCLI-D-13-00345.1.

Verbout, S. M., H. E. Brooks, L. M. Leslie, and D. M. Schultz, 2006: Evolution of the U.S. tornado database: 1954-2003. Wea. Forecasting, 21, 86-93, https://doi.org/10.1175/WAF910.1.

Weaver, S. J., S. Baxter, and A. Kumar, 2012: Climatic role of North American low-level jets on U.S. regional tornado activity. J. Climate, 25, 6666-6683, https://doi.org/10.1175/ JCLI-D-11-00568.1.

Welch, P., 1967: The use of fast Fourier transform for the estimation of power spectra: A method based on time averaging over short, modified periodograms. IEEE Trans. Audio Electroacoust., 15, 70-73, https://doi.org/10.1109/TAU.1967.1161901.

Widen, H. M., T. Fricker, and J. B. Elsner, 2015: New methods in tornado climatology. Geogr. Compass, 9, 157-168, https:// doi.org/10.1111/gec3.12205. 